\title{
Molecular Functions of Thyroid Hormone Signaling in Regulation of Cancer Progression and Anti-Apoptosis
}

\author{
Yu-Chin Liu ${ }^{1,2}$, Chau-Ting Yeh ${ }^{3}$ and Kwang-Huei Lin $1,2,3,4, * \mathbb{B}$ \\ 1 Department of Biochemistry, College of Medicine, Chang-Gung University, Taoyuan 333, Taiwan; \\ k1506820@gmail.com \\ 2 Department of Biomedical Sciences, College of Medicine, Chang-Gung University, Taoyuan 333, Taiwan \\ 3 Liver Research Center, Chang Gung Memorial Hospital, Taoyuan 333, Taiwan; chauting@adm.cgmh.org.tw \\ 4 Research Center for Chinese Herbal Medicine, College of Human Ecology, Chang Gung University \\ of Science and Technology, Taoyuan 333, Taiwan \\ * Correspondence: khlin@mail.cgu.edu.tw; Tel./Fax: +886-3-2118263
}

Received: 31 August 2019; Accepted: 5 October 2019; Published: 9 October 2019

\begin{abstract}
Several physiological processes, including cellular growth, embryonic development, differentiation, metabolism and proliferation, are modulated by genomic and nongenomic actions of thyroid hormones (TH). Several intracellular and extracellular candidate proteins are regulated by THs. 3,3,5-Triiodo-L-thyronine $\left(\mathrm{T}_{3}\right)$ can interact with nuclear thyroid hormone receptors (TR) to modulate transcriptional activities via thyroid hormone response elements (TRE) in the regulatory regions of target genes or bind receptor molecules showing no structural homology to TRs, such as the cell surface receptor site on integrin $\alpha \mathrm{v} \beta 3$. Additionally, L-thyroxine $\left(T_{4}\right)$ binding to integrin $\alpha v \beta 3$ is reported to induce gene expression through initiating non-genomic actions, further influencing angiogenesis and cell proliferation. Notably, thyroid hormones not only regulate the physiological processes of normal cells but also stimulate cancer cell proliferation via dysregulation of molecular and signaling pathways. Clinical hypothyroidism is associated with delayed cancer growth. Conversely, hyperthyroidism is correlated with cancer prevalence in various tumor types, including breast, thyroid, lung, brain, liver and colorectal cancer. In specific types of cancer, both nuclear thyroid hormone receptor isoforms and those on the extracellular domain of integrin $\alpha v \beta 3$ are high risk factors and considered potential therapeutic targets. In addition, thyroid hormone analogs showing substantial thyromimetic activity, including triiodothyroacetic acid (Triac), an acetic acid metabolite of $\mathrm{T}_{3}$, and tetraiodothyroacetic acid (Tetrac), a derivative of $\mathrm{T}_{4}$, have been shown to reduce risk of cancer progression, enhance therapeutic effects and suppress cancer recurrence. Here, we have reviewed recent studies focusing on the roles of THs and TRs in five cancer types and further discussed the potential therapeutic applications and underlying molecular mechanisms of THs.
\end{abstract}

Keywords: thyroid hormone; thyroid hormone receptor; 3,3,5-triiodo-L-thyronine ( $\left.\mathrm{T}_{3}\right)$, L-thyroxine $\left(\mathrm{T}_{4}\right)$, cancer proliferation

\section{Introduction}

Thyroid hormone (TH) in adults is necessary for the regulation of multiple physiological effects, such as cell growth, structure, and metabolism [1]. The main thyroid hormones produced by the thyroid gland are thyroxine $\left(\mathrm{T}_{4}\right), 3,5,3^{\prime}$-triiodothyronine $\left(\mathrm{T}_{3}\right)$, and reverse $3,5,3^{\prime}$-triiodothyronine $\left(\mathrm{rT}_{3}\right)$, which are controlled by thyroid-stimulating hormone (TSH). Under physiological conditions, both $\mathrm{T}_{4}$ and $\mathrm{T}_{3}$ are secreted into the bloodstream by the thyroid gland [2]. THs circulating in the body exert metabolic effects on multiple organs, including heart, bone, brain, liver, thyroid, kidney 
and skeletal muscle [2]. The actions of thyroid hormone are classified into two main mechanisms: (1) A non-genomic effect initiated at the plasma membrane that regulates downstream gene expression via integrin $\alpha v \beta 3$; and (2) transcriptional activity induced by interactions with nuclear thyroid hormone receptor proteins and further binding to thyroid hormone response elements of specific downstream genes. The $\alpha v \beta 3$ isoform of integrin is a heterodimeric structure at the plasma membrane capable of interacting with a large number of extracellular matrix (ECM) proteins as ligands for activating downstream signal pathways [3]. In addition, the protein structure of thyroid hormone receptor is similar to nucleus receptor superfamily and acts as a sequence-specific ligand-dependent transcription factor that mediates several downstream effects of THs on activation or repression of target genes [4]. The above actions generated through either non-genomic or genomic effects overlap in the nucleus. Thyroid hormone activity is beneficial for normal cell development. However, when both the levels of THs and thyroid hormone receptors in the body are out of control, it causes multiple diseases, including cardiovascular disease, diabetes mellitus and chronic liver disease [5]. Earlier studies by our group and other investigators conducted to clarify the significance of thyroid hormone in cells and tissues have revealed activity in regulation of proliferation of both tumor and nonmalignant cells. The current review focuses on the potential association between thyroid hormones and progression of different cancer types.

\section{Thyroid Hormone Effects via Interactions with the Thyroid Hormone Receptor}

\subsection{Thyroid Hormone}

The thyroid hormone system starts from the hypothalamus, where thyrotropin-releasing hormone (TRH) is synthesized and released from the periventricular nucleus (PVN). TRH binding to its receptor on the thyrotroph of the anterior pituitary gland stimulates proliferation, synthesis and secretion of thyroid stimulating hormone (TSH). TSH subsequently interacts with the TSH receptor (TSHR) on individual thyroid follicular cells of the thyroid gland to stimulate synthesis and release of thyroid hormones L-thyroxine $\left(\mathrm{T}_{4}\right)$ and 3,3,5-triiodo-L-thyronine $\left(\mathrm{T}_{3}\right)$ [6]. In addition, thyroglobulin, a dimeric protein, is synthesized in the rough endoplasmic reticulum of thyroid follicular cells and secreted to enter the follicular colloid via exocytosis. Simultaneously, iodide $\left(\mathrm{I}^{-}\right)$is transported to thyroid follicular cells via sodium-iodide $(\mathrm{Na} / \mathrm{I})$ symporter pump activity and enters thyroid follicular cells from the cytoplasm in a pendrin-dependent manner. One of the enzymes in the follicular colloid, thyroid peroxidase, catalyzes iodide $\left(\mathrm{I}^{-}\right)$oxidization to iodine $\left(\mathrm{I}^{0}\right)$. Iodine $\left(\mathrm{I}^{0}\right)$ iodinates thyroglobulin and conjugates with the protein chain of tyrosyl residues. Subsequently, thyroglobulin re-enters thyroid follicular cells via endocytosis and undergoes proteolysis via actions of various proteases to liberate thyroxine $\left(T_{4}\right)$ and 3,3,5-triiodo-L-thyronine $\left(T_{3}\right)$. Efflux of $T_{4}$ and $T_{3}$ from thyroid follicular cells to various target cells is achieved through specific membrane transporter proteins [7], such as monocarboxylate transporter (MCT) 8 and 10 [8,9], the organic anion transporter protein-1c1 (OATP1c1), and nonspecific L-type amino acid transporters 1 and 2 (LAT1, LAT2) [10]. However, earlier studies indicate that euthyroid status in blood with circulating $\mathrm{T}_{4}$ and $\mathrm{T}_{3}$ is controlled by a negative feedback loop mediated by the hypothalamus-pituitary-thyroid (HPT) set axis [11].

\subsection{Thyroid Hormone Receptor}

Circulating THs interact with thyroid hormone receptors to promote downstream signaling pathways and activate transcription factors. Thyroid hormone receptors (TR) including TR $\alpha$ and TR $\beta$ contain several domains, specifically, amino terminal $A / B$ that may function as a gene enhancer, DNA-binding domain (DBD), hinge region containing the nuclear localization signal and carboxy-terminal ligand-binding domain that binds $\mathrm{T}_{3}$ (Figure 1 ). These receptors display protein structures similar to most nuclear receptors and each domain performs specific functions $[4,12-15]$. In particular, the amino-terminal A/B of thyroid hormone receptors (TR $\beta 1$ and TR $\beta 2$ ) is generated from a signaling gene via alternative splicing or usage of alternative promoters [16]. The four major 
TR isoforms, TR $\alpha 1, \mathrm{TR} \alpha 2$, TR $\beta 1$, and TR $\beta 2$, are produced by c-erbA $\alpha$ and c-erbA $\beta$ genes. Their human homologs are designated THRA and THRB. The c-erbA $\alpha$ gene located on chromosome 17 encodes two different TR $\alpha$ isoforms. One is functional TH-binding TR $\alpha 1$ and the other is a dominant-negative splice variant, TR $\alpha 2$, lacking TH binding activity [17]. TR $\alpha 2$ is unique in consideration of its lack of binding to THs while interacting with DNA, and its precise function is unclear at present. The c-erbA $\beta$ gene located on chromosome 3 encodes two isoforms, TR $\beta 1$ and TR $\beta 2$, that participate in TH binding and are widely distributed in a tissue-specific manner. TR $\alpha 1$ and TR $\alpha 2$ are expressed in the kidney, skeletal muscle, lungs, heart, and testes, with particularly high levels detected in the brain [18]. TR $\beta 1$ expression is significant in brain, thyroid, liver, and kidney while the TR $\beta 2$ isoform is specifically expressed in the anterior pituitary, hypothalamus, and developing brain [12,19-21] (Figure 1).

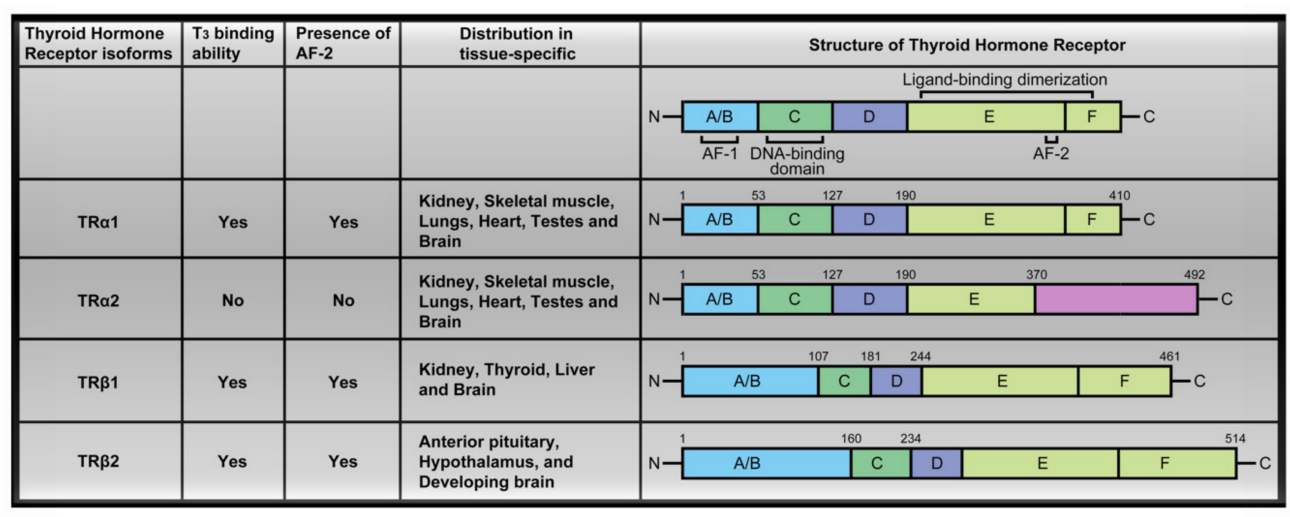

\begin{tabular}{l|l|l|l|l|l}
$A$ & Amino terminal A/B & $C$ & DNA-binding domain (DBD) & Hinge region & $E$
\end{tabular}

Figure 1. TR isoforms and structure distribution. Thyroid hormone receptors (TR) contain several domains, specifically, the amino terminal A/B that may function as a gene enhancer, the DNA-binding domain (DBD), the hinge region containing the nuclear localization signal and the carboxy-terminal ligand-binding domain that binds $\mathrm{T}_{3}$. The four major TR isoforms are TR $\alpha 1$, TR $\alpha 2$, TR $\beta 1$, and TR $\beta 2$. TH binding is widely distributed in a tissue-specific manner such as TR $\alpha 1$ and TR $\alpha 2$ expressed in the kidney, skeletal muscle, lungs, heart, and testes, with particularly high levels detected in the brain. TR $\beta 1$ expression is significant in the brain, thyroid, liver, and kidney while the TR $\beta 2$ isoform is specifically expressed in the anterior pituitary, hypothalamus, and developing brain.

Interestingly, TR $\alpha 1, T R \alpha 2$ and TR $\beta 1$ are overexpressed in various tissues in the human body excepting the liver, the major TH target organ [17]. Additionally, TRs regulate transcriptional activity through associating with other nuclear receptors such as retinoid $X$ receptor $(R X R)$, retinoic acid receptor subtypes, and vitamin D receptor (VDR), which are homo or heterodimers (Figure 2A). TRs/RXR belong to non-permissive heterodimers that can be activated transcriptionally by TRs ligand but not by RXR ligand alone (Figure 2A). In particular, RXR forms a heterodimer with TRs that influence downstream target gene expression by binding to specific DNA sequences located in regulatory regions known as thyroid hormone elements (TRE) [22-24]. TREs within the promoter region contain individual DNA sequences (A/G)GGT(C/A/G)A, designated "half-sites", that are recognized by TRs. The half-site sequences in TREs incorporate palindromic (Pal), direct repeat (DR) and inverted repeat arrangements (IP) [15] (Figure 2B). In the absence of thyroid hormone in cells, TRs interacting with TREs do not influence gene expression. TRs enter the nucleus and bind to DNA until arrival of the thyroid hormone. 
A. Non-permissive heterodimer
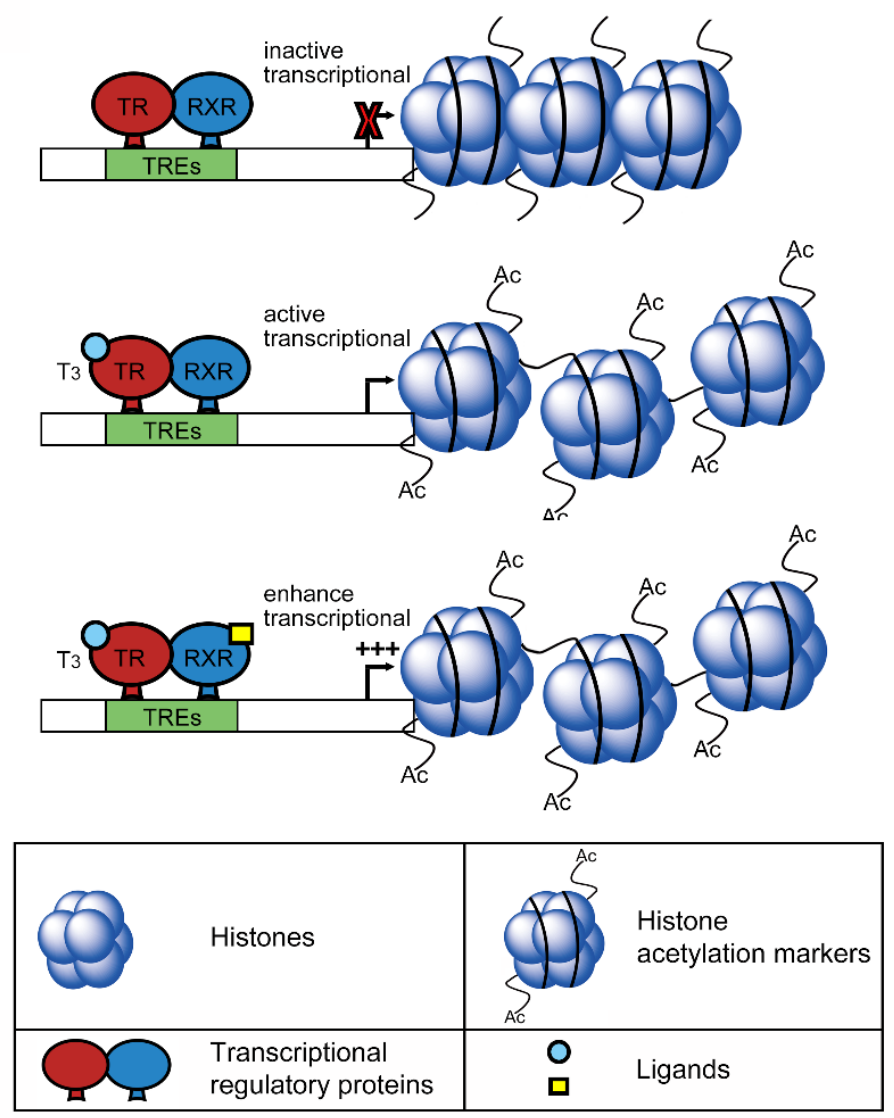

B.

Consensue TRE sequence

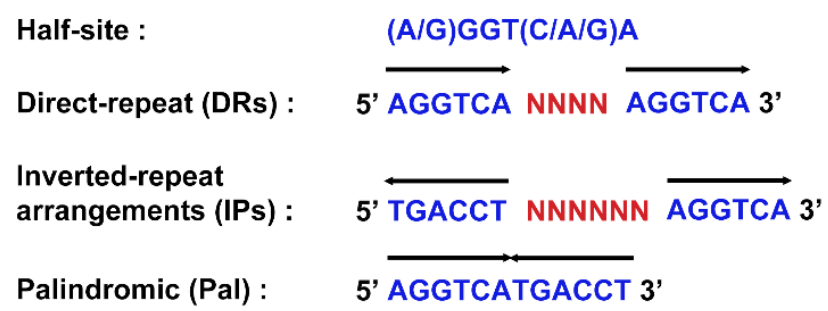

Figure 2. Schematic representation of TRs/RXR non-permissive heterodimers and consensus TRE half-sites. (A) TRs/RXR belong to non-permissive heterodimers that can be activated transcriptionally by TRs ligand but not by RXR ligand alone. Moreover, TRs/RXR can enhance the transcriptional response by binding of the RXR ligand and TRs ligand. (B) TREs within the promoter region contain individual DNA sequences (A/G)GGT(C/A/G)A, designated "half-sites", that are recognized by TRs. The half-site sequences in TREs incorporate palindromic (Pal), direct repeat (DR) and inverted repeat arrangements (IP).

\subsection{Nuclear Transcriptional Activity of Thyroid Hormone}

Several recent studies have focused on transcriptional activation induced by TR binding to positive TRE sites. However, TRs play a dual modulatory role and can also repress gene expression in a ligand-dependent manner. TRs bind to their respective TREs as monomers, homodimers or heterodimers with retinoid X receptors (RXR). Heterodimers of TR/RXR contain LBDs that interact with $T_{3}$. Additionally, DBD displays high affinity for DNA sequences of TREs [25]. TRs can 
directly or indirectly associate with different molecular proteins (transcription factors, coactivators, transcription intermediary factors (TIF) and corepressors) to influence downstream target gene expression. Biochemical analyses have demonstrated that nuclear receptor corepressor (NCoR) and homolog, silencing mediator of retinoic and thyroid receptor (SMRT), are strongly associated with unliganded TR [26]. A number of studies suggest that the corepressor interacts with the TR homodimer but not monomer on DNA. Recruitment of NCoR and SMRT to the promoter via association with DBD of TR/RXR leads to strong repression of basal promoter activity of target genes. NCoR and SMRT are structurally and functionally similar. Both proteins contain three repressor domains (RD1, RD2, and RD3) and two receptor-interacting domains (RID). RD1 interacts with TBL1 and mSin3, which recruit class I deacetylases (HDAC1 and HDAC2). HDAC3 interacts directly with RD2. Moreover, class II deacetylases (HDAC4/5 and HDAC7) bind RD3 as a mediator for repressing downstream genes transcription. In other words, RD1, RD2 and RD3 domains of corepressors interact with different types of deacetylase and other proteins to form a large repressor complex that suppresses target gene transcription [27] (Figure 3A). Recent studies have shown strong links among histone acetylation, chromatin remodeling and gene regulation activities [28,29]. As specified above, NCoR and SMRT may function as corepressors via histone deacetylase activity for complex-mediated chromatin remodeling. HDACs and histone binding proteins RbAp46/48 associate with the homologs $\mathrm{mSin} 3 \mathrm{~A}$ and $\mathrm{mSin} 3 \mathrm{~B}$. HDACs are recruited to target genes by associating with Sin3 protein that interacts with sequence-specific DNA binding factors [30] (Figure 3B). The mSin3-HDAC complex is highly abundant and stable, facilitating binding and recruitment by the nuclear receptor repressors NCoR and SMRT [31,32]. Specifically, HDACs interact with mSin3 for TR/RXR-mediated repression. The TR/RXR/mSin 3 complexes are indirectly mediated by NCoR and SMRT, which function to link receptors to mSin3-HDAC complexes. NCoR and SMRT corepressors are reported to recruit class I deacetylases after interactions with adaptor $\mathrm{mSin} 3$ protein. However, biochemical research to date has failed to detect NCoR or SMRT in mSin3-HDAC complexes. Other class II histone deacetylases (HDAC4, HDAC5 and HDAC7) have been identified that associate with SMRT interacting-proteins and repress gene transcription (Figure $3 \mathrm{~B}$ ). Therefore, a single corepressor can mediate downstream target gene expression via class I HDAC complexes in a Sin3A-dependent manner or class II HDAC complexes in a Sin3A-independent manner. Furthermore, a novel SMRT-containing cellular complex incorporating HDAC3 and transducing beta-like protein 1 (TBL1), a protein that interacts with histone H3, has been identified (Figure 3B). In vivo, TBL1 is involved in a repressor complex that repression of gene transcription through is bridged to HDAC3 and further interactions with SMRT, and can potentiate repression via TR [33]. However, under TH presence conditions, the TR conformation is altered to allow dissociation of corepressors (NCoR or SMRT), subsequent recruitment of transcriptional coactivators and induction of target gene transcription. Multiprotein complexes designated 'TRAP' interact with TRs [34,35] (Figure 3B). Biochemical analyses have revealed binding of a series of proteins to TRs, the most abundant of those proteins are molecularly distinguished with a molecular mass of 140 or $160 \mathrm{kDa}$, designated p140 and p160 [34]. Steroid receptor coactivator 1 (SRC-1) is the first p160 family member identified as a coactivator and interacts with several nuclear receptors via C-terminal activation function-2 (AF-2) in the ligand binding domain (LBD), one of which is TR [36,37]. SRC-1 has been shown to enhance the transcriptional activity of a number of transcription factors [38]. SRC-1 and other SRC families of displaying coactivator structures contain a basic-helix-loop-helix (bHLH) and single-minded (PAS) domain, which interact with intermolecular or intramolecular substrates [39]. In addition, SRC-1 has a nuclear receptor interacting domain incorporating three LXXLL amino acid motifs, which are not only required for nuclear receptor binding but also recruit specificity to other proteins [40-42]. Another significant finding is that SRC-1 coactivators contain two activation domains in the C-terminal region, denoted AD1 and AD2. The stronger transactivation domain, AD1, interacts with co-integrator CREB binding protein (CBP) [43] and another weaker activation domain in the far C-terminal region while AD2 interacts with an arginine methyltransferase, CARM1 (Figure 3A). A number of studies suggest that the SRC family acts as a platform for recruitment of other proteins. 
Histone acetyltransferase (HAT) activity is possessed by CREB-binding protein (CBP)/p300 and p300/CBP-associated factor ( $\mathrm{p} / \mathrm{CAF})$, which modulate chromatin remodeling $[44,45]$ via acetylation of histone $\mathrm{H} 3$ and $\mathrm{H} 4$ (Figure 3A,B). SRC-1 also plays a potential adapter role and is capable of interacting with specific basal transcription factors, such as TATA binding factor (TBP) and transcription factor IIB [46]. Multiprotein complexes known as TR-associated proteins (TRAP) have been identified that interact with TRs [34,35]. These complexes can indirectly interact with TRs in response to ligand binding via a receptor-interacting LXXLL motif in the p160 coactivator through TRAP 220 [47]. In a cell-free transcription system with chromatin templates, ligand activity of TRs is enhanced by the TRAP complex, as determined from studies on SRC-1 [48] (Figure 3B). Several investigations to date indicate that ligand-dependent transcriptional activity of TRs requires recruitment of p160-TRAP coactivator complexes but the function association between TRAP complexes and the $\mathrm{p} 160 / \mathrm{CBP} / \mathrm{PCAF}$ system is unclear. For example, both TRAPs and p160/CBP/PCAF interact with the same region of TRs but do not bind simultaneously, and the molecule that binds first is yet to be established.

A.

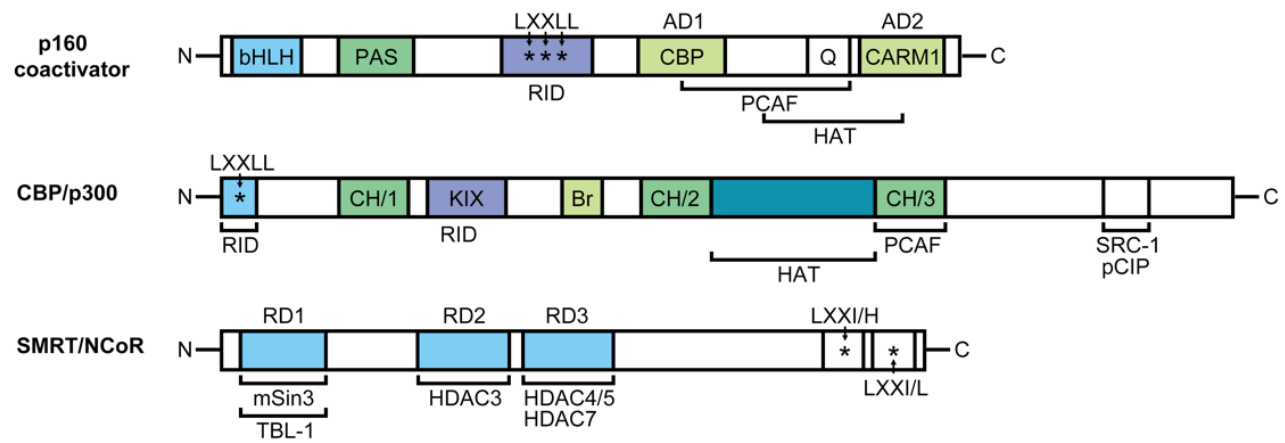

B.

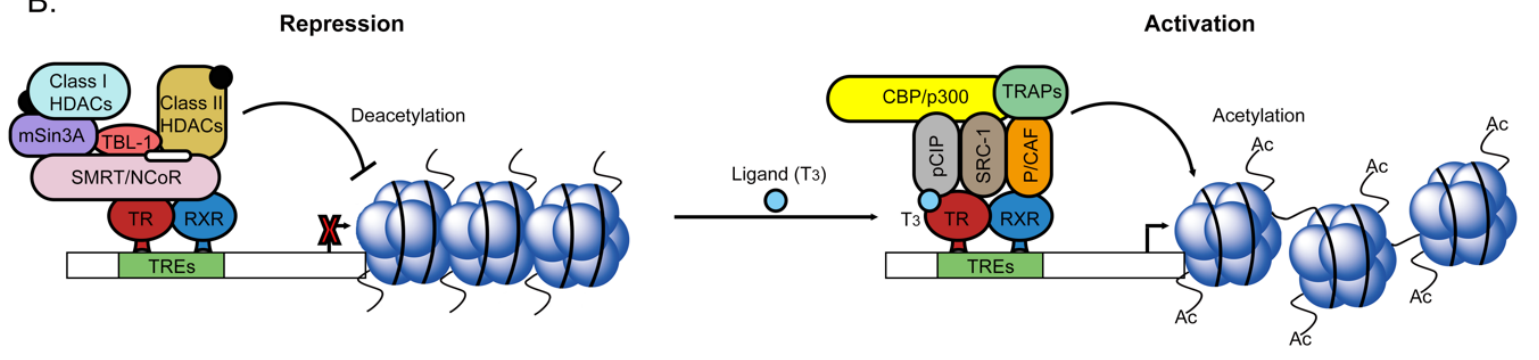

Figure 3. Schematic representation of the structure of receptor coactivators and corepressors and molecular action to regulation of genes transcription activity. (A) Biochemical analyses have revealed binding of a series of coactivators proteins to TRs, the most abundant of those proteins such as p160 family, and histone acetyltransferase (HAT), CREB-binding protein (CBP)/p300. Additionally, nuclear receptor corepressor (NCoR) and homolog, silencing mediator of retinoic and thyroid receptor (SMRT), are strongly associated with unliganded TR. (B) TRs repress gene expression in a ligand-dependent manner. TRs bind to their respective TREs with retinoid $X$ receptors (RXR). Heterodimers of TR/RXR contain LBDs that interact with $\mathrm{T}_{3}$. Additionally, DBD displays high affinity for DNA sequences of TREs. TRs can directly or indirectly associate with different molecular proteins (transcription factors, coactivators, transcription intermediary factors (TIF) and corepressors) to influence downstream target gene expression.

\subsection{Non-Genomic Actions of Thyroid Hormone}

The preliminary studies have revealed in the mitochondria and cytoskeleton that action of thyroid hormone that is not primarily involved in nuclear activities $[49,50]$. These actions are rapid in contrast to transcription and translation processes that occur over minutes or hours and are not exerted through gene transcription or protein synthesis, leading to coining of the term "non-genomic effects". Non-genomic activity of the thyroid hormone in enucleate cells, plasma membrane and other cell fractions in vitro has been identified. According to these earlier studies, thyroid hormone receptors 
on integrin $\alpha \mathrm{v} \beta 3$ are not homologous to nuclear thyroid hormone receptors. THs affect multiple physiological activities within the cell via interactions with integrin $\alpha \mathrm{v} \beta 3$ [51]. The integrin family has 24 structural proteins in the plasma membrane that essentially regulate cell-cell and cell-extracellular matrix (ECM) protein interactions [52]. $\alpha \mathrm{V} \beta 3$, one of the isoforms of integrin, is heterodimeric in structure and contains an Arg-Gly-Asp (RGD) recognition specific binding site for ECM proteins, such as osteopontin, fibronectin and vitronectin, for activation of intracellular signaling [52]. In other words, thyroid hormones bind the receptor near the RGD site of integrin $\alpha v \beta 3$ that serves as a recognition and binding motif for ECM proteins [53]. Upon interaction of integrin $\alpha \mathrm{v} \beta 3$ with THs $\left(\mathrm{T}_{3}\right.$ and $\left.\mathrm{T}_{4}\right)$, mitogen-activated protein kinase/extracellular signal-regulated kinase (MAPK/ERK 1/2) pathways are activated that regulate multiple cellular physiological processes [51] (Figure 4A). Integrin $\alpha \mathrm{v} \beta 3$ contains two binding domains: (1) S1 that specifically recognizes $T_{3}$ and activates the phosphatidylinositol 3-kinase (PI3K)/Akt/protein kinase B (PKB) pathway via stimulation of Src kinase (Figure 4B) and (2) S2 that binds both $\mathrm{T}_{3}$ and $\mathrm{T}_{4}$, leading to regulation of MAPK/ERK1/2 (Figure $4 \mathrm{~A}$ ). $\mathrm{T}_{4}$ has high affinity for the $\mathrm{S} 2$ domain while both $\mathrm{S} 1$ and $\mathrm{S} 2$ domains interact with $\mathrm{T}_{3}$. In addition, the two binding domains mediate distinct downstream effects. For instance, Src kinase and PI3K pathways are activated by $\mathrm{T}_{3}$ binding to the $\mathrm{S} 1$ domain, leading to direct trafficking of TR $\alpha 1$ from the cytoplasm to the nucleus and transcriptional activity of the target gene, HIF1A (Figure 4B). The S2 domain stimulates activation of MAPK/ERK1/2 via phospholipase C (PLC) and protein kinase $\mathrm{C} \alpha(\mathrm{PKC} \alpha)$, promoting phosphorylation of nucleoproteins TRP1, ERM, STAT1 and p35 $[54,55]$ and modulation of intracellular protein trafficking of estrogen receptor $\alpha(\mathrm{ER} \alpha)$ and nuclear uptake of TR $\beta$ from the cytoplasm [56,57] (Figure 4A). Notably, estrogen receptor $\alpha(E R \alpha)$ in this pathway is phosphorylated, suggestive of crosslinking between thyroid and steroid hormone pathways [58]. These represent two of the five mechanisms underlying the non-genomic action of thyroid hormone. In the cytoplasm, the PI3K pathway is rapidly activated via $T_{3}$ interactions with TR $\beta 1$ and initiates downstream target gene transcription (Figure $4 \mathrm{C}$ ). Interactions of $\mathrm{T}_{3}$-liganded TR $\beta 1$ with the regulatory p $85 \alpha$ subunit of PI3K that induces downstream AKT phosphorylation lead to subsequent phosphorylation of mTOR and further activation of mTOR-p70S6K along with a series of downstream target genes in the nucleus, such as hypoxia inducible factor- $1 \alpha$ (HIF-1 $\alpha$ ), glucose transporter 1 (GLUT1), platelet-type phosphofructokinase (PFKP) and monocarboxylate transporter 4 (MCT 4) [59-61] (Figure 4C). Additionally, at the plasma membrane, $\mathrm{T}_{3}$ interacts with truncated TR $\alpha 1$ (p30 TR $\alpha 1$ ), and binding of PI3K to p85 $\alpha$ inactivates transcription of downstream genes. However, the $\mathrm{T}_{3}$-liganded $\mathrm{TR} \alpha 1$ complex activates a series of signal transduction proteins (PKGII and ERK) and nitric oxide synthase (NOS) (Figure 4D). Additionally, $\mathrm{T}_{3}$ interactions with TR $\beta 1$ are reported to modulate $\mathrm{Na}$, K-ATPase activity via activation of both MAPK/ERK $1 / 2$ and PI3K pathways (Figure 4C,E). However, only $\mathrm{T}_{3}$-liganded TR $\beta 1$ stimulates MAPK/ERK 1/2 activity, which activates the sodium proton exchanger $\left(\mathrm{Na}^{+} / \mathrm{H}^{+}\right)$in the plasma membrane $[57,62]$ (Figure 4E). 


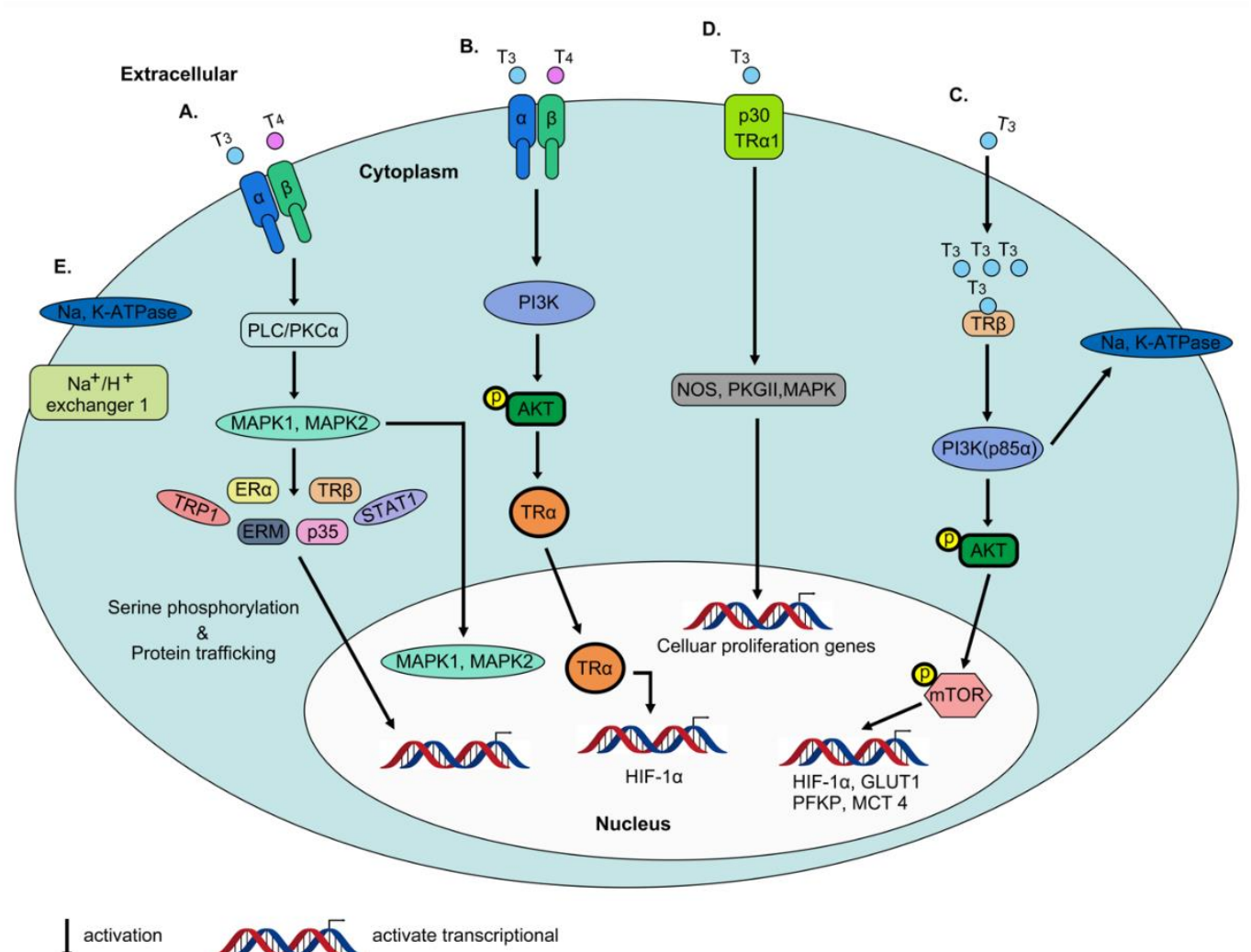

Figure 4. Non-genomic actions of thyroid hormone. THs affect multiple physiological activities within the cell via interactions with integrin $\alpha \mathrm{v} \beta 3$. (A) $\alpha \mathrm{v} \beta 3$ that binds both $T_{3}$ and $T_{4}$, leading to regulation of MAPK/ERK1/2 via PLC and PKC $\alpha$, promoting phosphorylation of nucleoproteins TRP1, ERM, STAT1 and p35 and modulation of intracellular protein trafficking of ER $\alpha$ and nuclear uptake of TR $\beta$ from the cytoplasm. (B) $\alpha \mathrm{v} \beta 3$ that specifically recognizes $\mathrm{T}_{3}$ and activates the PI3K/Akt/PKB pathway via stimulation of Src kinase, leading to direct trafficking of TR $\alpha 1$ from the cytoplasm to the nucleus and transcriptional activity of the target gene, HIF-1 $\alpha$. (C) In the cytoplasm, the PI3K pathway is rapidly activated via $T_{3}$ interactions with TR $\beta 1$ and initiates downstream target gene transcription including HIF-1 $\alpha$, GLUT1, PFKP and MCT 4. (D) At the plasma membrane, $\mathrm{T}_{3}$ interacts with $\mathrm{p} 30 \mathrm{TR} \alpha 1$, and binding of PI3K to $\mathrm{p} 85 \alpha$ inactivates transcription of downstream genes. However, the $\mathrm{T}_{3}$-liganded TR $\alpha 1$ complex activates a series of signal transduction proteins (PKGII and ERK) and NOS. (E) $T_{3}$-liganded TR $\beta 1$ stimulates MAPK/ERK $1 / 2$ activity, which activates the sodium proton exchanger $\left(\mathrm{Na}^{+} / \mathrm{H}^{+}\right)$in the plasma membrane.

\section{Functional Significance of Thyroid Hormone and Receptors in Tumors}

Under physiological conditions, thyroid hormone receptors control tumor cell proliferation and cancer cell defense pathways [54,59,63]. TRs are reported to exert tumor suppressor effects [64], with $96 \%$ nuclear TR $\beta 1$ expression detected in the normal epithelium but lower frequency of expression in adenomas $(\sim 83 \%)$ and cancer $(68 \%)$, which is significantly lower than that in normal tissue and adenoma). Consistently, another study demonstrated a tumor suppressor role of wild-type TR $\beta 1$ in thyroid cancer [65-67], similar to that in other cancer types [67,68]. Conversely, abnormal expression or mutation of TR $\beta 1$ has been shown to promote carcinogenesis [69]. Interestingly, clinical data on BRCA1-associated breast cancer suggest that TR $\beta 1$ expression can extend the overall survival curve. However, wild-type TR $\alpha$ was positively associated with reduced five-year overall survival for five years [70]. Wild-type TR $\alpha$ plays a distinct role in cancer relative to TR $\beta 1$, which TR $\alpha$ potentially influences tumorigenesis and hematogenous metastasis via association with $n m 23$ genes [64,70]. Additionally, $\mathrm{TR} \alpha$ binding to $\mathrm{T}_{3}$ promotes gastrointestinal cancer development through directly modulating the transcriptional activity of $\beta$-catenin and affecting downstream signal transduction [71]. 
Thyrotropin, THs, integrin $\alpha \mathrm{v} \beta 3$ and deiodinases are involved in cancer proliferation along with TRs. Earlier studies suggest that altered TH status modulates cancer cell proliferation and tumor growth. For example, low expression of circulating thyrotropin releasing hormone (TRH) is associated with increased risk of lung, colon, prostate, and breast cancer [72]. Hyperthyroidism in rodents stimulates tumor transplant growth and metastasis, and conversely, hypothyroidism suppresses these effects [73]. Furthermore, both breast and prostate cancers at advanced clinical stages display high expression of THs. Spontaneous hypothyroidism may beneficially alter the course and aggressiveness of breast cancer [74]. Clearly, TH expression is correlated with cancer initiation. In the following section, the underlying mechanisms modulating proliferation and metastasis of different cancer types, including thyroid hormone effects, deiodinase activities and thyroid hormone receptors, are discussed (Table 1).

Table 1. Summary of the relevant molecular mechanism in different kinds of cancer via THs/TRs.

\begin{tabular}{|c|c|c|c|c|c|}
\hline Cancer Types & Thyroxine & $\begin{array}{l}\text { Binding } \\
\text { Receptor }\end{array}$ & Molecular Mechanisms & $\begin{array}{l}\text { Physiological } \\
\text { Processes }\end{array}$ & Ref. \\
\hline \multirow[t]{5}{*}{ Breast cancer } & $\mathrm{T}_{3}, \mathrm{~T}_{4}$ & $\alpha v \beta 3$ & activation of MAPK/ERK1/2 & proliferation $\uparrow$ & {$[58,75]$} \\
\hline & $\mathrm{T}_{3}$ & $\alpha v \beta 3$ & $\begin{array}{l}\text { downregulation of } \\
\text { SMP30 gene }\end{array}$ & $\begin{array}{l}\text { anti-cancer } \uparrow, \\
\text { apoptosis } \uparrow\end{array}$ & [76] \\
\hline & $\mathrm{T}_{3}$ & $\mathrm{TR} \beta$ & downregulation of $\mathrm{T} 1$ gene & proliferation $\downarrow$ & [77] \\
\hline & $\mathrm{T}_{3}$ & $\operatorname{TR} \beta$ & $\begin{array}{c}\text { inhibition of STAT5 } \\
\text { signaling }\end{array}$ & development $\downarrow$ & {$[78]$} \\
\hline & $\mathrm{T}_{3}$ & $\operatorname{TR} \beta$ & downregulation of $\beta$-catenin & prognosis $\uparrow$ & [70] \\
\hline \multirow[t]{3}{*}{ Thyroid cancer } & $\mathrm{T}_{3}, \mathrm{~T}_{4}$ & $\alpha v \beta 3$ & activation of MAPK/ERK1/2 & $\begin{array}{r}\text { proliferation } \uparrow, \\
\text { anti-apoptosis } \uparrow\end{array}$ & [79] \\
\hline & $\mathrm{T}_{3}$ & $\operatorname{TR} \beta \Delta$ & activation of PI3K-Akt & $\begin{array}{c}\text { metastatic } \downarrow \text {, } \\
\text { development } \uparrow\end{array}$ & [80] \\
\hline & $\mathrm{T}_{3}$ & $\operatorname{TR} \beta$ & $\begin{array}{c}\text { inhibition of PI3K-Akt } \\
\text { increase p27 } \\
\text { decrease cyclin D }\end{array}$ & $\begin{array}{c}\text { tumor growth } \uparrow \\
\text { proliferation } \downarrow\end{array}$ & {$[80]$} \\
\hline Lung cancer & $\mathrm{T}_{3}, \mathrm{~T}_{4}$ & $\alpha v \beta 3$ & $\begin{array}{c}\text { increase proliferating cell } \\
\text { nuclear antigen (PCNA) } \\
\text { induce ER } \alpha \\
\text { phosphorylation }\end{array}$ & proliferation $\uparrow$ & [81] \\
\hline \multirow[t]{3}{*}{ Brain tumor } & $\mathrm{T}_{3}, \mathrm{~T}_{4}$ & $\alpha v \beta 3$ & $\begin{array}{l}\text { activation of MAPK/ERK1/2 } \\
\text { increase proliferating cell } \\
\text { nuclear antigen (PCNA) }\end{array}$ & tumor growth $\uparrow$ & {$[57,82-84]$} \\
\hline & $\mathrm{T}_{3}$ & $\mathrm{TR} \beta$ & $\begin{array}{l}\text { activation of MAPK/ERK1/2 } \\
\text { activation of PI3K-Akt } \\
\text { upregulation of HIF- } 1 \alpha \text { gene }\end{array}$ & proliferation $\uparrow$ & [57] \\
\hline & $\mathrm{T}_{3}$ & $\mathrm{TR} \alpha$ & $\begin{array}{l}\text { expression of TR } \alpha 1 \\
\text { and } T R \alpha 2\end{array}$ & $\begin{array}{l}\text { tumor grade } \downarrow \text {, } \\
\text { tumor } \\
\text { malignancy } \downarrow\end{array}$ & [85] \\
\hline \multirow[t]{4}{*}{ Liver cancer } & $\mathrm{T}_{3}$ & $\operatorname{TR} \alpha, \operatorname{TR} \beta$ & $\begin{array}{c}\text { downregulation of CDK2, } \\
\text { cyclin } \mathrm{E}, \\
\text { phosphorylation- } \mathrm{Rb} \\
\text { upregulation of } \mathrm{p} 21\end{array}$ & proliferation $\uparrow$ & {$[86,87]$} \\
\hline & $\mathrm{T}_{3}, \mathrm{~T}_{4}$ & $\alpha v \beta 3$ & $\begin{array}{c}\text { induction of DKK4 } \\
\text { reduction of MMP2 } \\
\text { downregulation of ELF2 }\end{array}$ & $\begin{array}{c}\text { cell invasion } \downarrow \\
\text { metastatic } \downarrow\end{array}$ & {$[88,89]$} \\
\hline & $\mathrm{T}_{3}$ & $\mathrm{TR} \alpha \Delta$ & $\begin{array}{l}\text { dysregulation of follistatin, } \\
\text { activin } \beta C \text {, thrombomodulin, } \\
\text { SIX1, Rasgrp3, Ndrg2 }\end{array}$ & $\begin{array}{l}\text { development } \uparrow, \\
\text { carcinogenesis } \uparrow\end{array}$ & [90] \\
\hline & $\mathrm{T}_{3}$ & $\mathrm{TR} \alpha$ & upregulation of lipocalin 2 & $\begin{array}{r}\text { invasion } \uparrow, \\
\text { metastasis } \uparrow\end{array}$ & [91] \\
\hline
\end{tabular}


Table 1. Cont.

\begin{tabular}{|c|c|c|c|c|c|}
\hline Cancer Types & Thyroxine & $\begin{array}{l}\text { Binding } \\
\text { Receptor }\end{array}$ & Molecular Mechanisms & $\begin{array}{l}\text { Physiological } \\
\text { Processes }\end{array}$ & Ref. \\
\hline \multirow{6}{*}{$\begin{array}{l}\text { Colorectal } \\
\text { cancer }\end{array}$} & $\mathrm{T}_{4}$ & $\operatorname{TR} \alpha, \operatorname{TR} \beta$ & $\begin{array}{c}\text { activation of NF- } \mathrm{KB} \\
\text { activation of BM1 gene }\end{array}$ & $\begin{array}{l}\text { cancer stem } \\
\text { like cell } \uparrow \\
\text { drug } \\
\text { resistance } \uparrow\end{array}$ & [92] \\
\hline & $\mathrm{T}_{3}$ & $\alpha v \beta 3$ & activation of ERK1/2/Akt & tumor growth $\uparrow$ & [93] \\
\hline & $\mathrm{T}_{3}, \mathrm{~T}_{4}$ & $\operatorname{TR} \alpha$ & activation of MET/FAK & $\begin{array}{c}\text { invasion } \uparrow, \\
\text { metastasis } \uparrow\end{array}$ & [94] \\
\hline & $\mathrm{T}_{4}$ & $\alpha v \beta 3$ & $\begin{array}{l}\text { increase proliferating cell } \\
\text { nuclear antigen (PCNA), } \\
\text { cyclin D1, c-myc }\end{array}$ & proliferation $\uparrow$ & {$[95,96]$} \\
\hline & $\mathrm{T}_{4}$ & $\mathrm{TR} \alpha$ & activation of NF- $\mathrm{kB}$ & $\begin{array}{c}\text { Tumor } \\
\text { progression } \uparrow, \\
\text { metastasis } \uparrow\end{array}$ & [97] \\
\hline & $\mathrm{T}_{3}$ & $\mathrm{TR} \alpha 1$ & $\begin{array}{l}\text { activation of Frizzled-related } \\
\text { protein, sFRP2 } \\
\text { modulation of } \beta \text {-catenin }\end{array}$ & proliferation $\uparrow$ & [98] \\
\hline
\end{tabular}

\subsection{Breast Cancer}

Thyroid hormone activity is related to breast cancer. Hypothyroidism is associated with low incidence of breast cancer, and conversely, hyperthyroidism with high incidence and aggressiveness of breast cancer [99]. Statistical studies suggest that high $\mathrm{T}_{3}$ levels in women are associated with increased overall risk and occurrence of breast cancer. A study on 1322 peri/postmenopausal women disclosed a significant direct correlation between $T_{3}$ level and breast cancer occurrence [100]. High $\mathrm{T}_{4}$ and $\mathrm{T}_{3}$ expression in the blood leads to subclinical hyperthyroidism in menopausal breast cancer patients [101]. On the other hand, the most frequent endocrine disorders are encountered in breast cancer. An earlier clinical study showed that among 844 breast cancer patients, 74 were hypothyroid and not only older but also diagnosed at an earlier stage than euthyroid patients [74]. Hypothyroidism is reported to promote breast cancer apoptosis and suppress mammary carcinogenesis through alterations in body composition, including leptin secretion and serum 17 $\beta$-estradiol (E2) [102]. Additionally, hypothyroidism can decrease inherent drug resistance and induce chemotherapy sensitivity [103]. Evidence of overlap of both non-genomic and genomic actions of thyroid hormones (THs) in breast cancer cells and crosslinking with other hormones, such as estrogens and testosterone, has been uncovered. TH-induced phosphorylation of estrogen receptor $\alpha(E R \alpha)$ at Ser-118 via activation of the MAPK/ERK 1/2 pathway promotes human breast cancer cell proliferation [58,75]. In human breast cell lines MCF-7 and T47D, both $\mathrm{T}_{4}$ and $\mathrm{T}_{3}$ promote cell proliferation in a dose-dependent manner [104-106]. Hyperthyroidism and hypothyroidism are correlated with the incidence of tumor induction and reduction and aggressiveness of breast cancer in female mice [99]. Interestingly, other reports support anticancer activity of THs, for instance, via downregulation of SMP30 expression and induction of apoptosis in MCF-7 cells through $\mathrm{T}_{3}$ [76]. Both $\mathrm{T}_{4}$ and $\mathrm{T}_{3}$ have been shown to regulate the breast cancer process. $\mathrm{T}_{4}$ only appears to interact with cell surface receptors of the hormone whereas $T_{3}$ binds nuclear THRs via genomic activity as well as integrin $\alpha v \beta 3$ in the cytoplasm [107]. As stated above, physiological free $\mathrm{T}_{4}$ acts as a growth factor that influences cancer progression, anti-apoptosis and endothelial cell migration. The main function of $\mathrm{T}_{3}$ is to promote breast cancer cell division $[54,79,82,108,109]$. $T 1$ gene overexpression in breast adenocarcinoma is induced by mitogens, serum, specific oncogenes and cytokines [77] and inhibited under conditions of high $\mathrm{T}_{3}$ concentrations, leading to reduced breast cancer cell proliferation. In addition, $\mathrm{T}_{3}$ suppresses STAT5-mediated regulation of downstream target gene expression by inhibiting STAT5 signaling, which can associate with TR $\beta 1$ as a tumor suppressor protein and inhibit mammary hyperplasia development [78]. TR $\beta 1$ has been shown to function as a tumor suppressor in a number of cancer types (including breast, 
lung and thyroid cancer). In a xenograft mouse experiment, injection of MCF-7-Neo cells into athymic mice promoted rapid tumor development. Conversely, when MCF-7 TR $\beta$ was injected into athymic mice, tumor growth was inhibited through serum $17 \beta$-estradiol (E2) [78]. In nuclei of breast cancer cells, both TR $\beta$ and TR $\alpha$ proteins are expressed, with $74 \%$ of breast tumors highly expressing TR $\alpha 1$ and $40 \% \mathrm{TR} \alpha 2$. TR $\alpha 2$ influences prognostic histopathological parameters in breast cancer patients, such as tumor size, axillary lymph node involvement, grading and hormone receptor status, leading to improvement of overall survival [110,111].

\subsection{Thyroid Cancer}

Three morphological subtypes (papillary thyroid carcinoma, follicular thyroid carcinoma (FTC) and anaplastic carcinoma) constitute $90 \%$ of all thyroid cancer types [112]. The majority of studies indicate that thyroid cancer is commonly associated with hyperthyroidism [4,113]. $\mathrm{T}_{4}$ induces proliferation of most human carcinoma cells (including follicular and papillary thyroid carcinoma cell lines) through binding to cell surface receptors on integrin $\alpha v \beta 3$. Interactions of $T_{4}$ with integrin $\alpha v \beta 3$ lead to inhibition of p53-dependent apoptosis in tumor cells. Additionally, in differentiated thyroid carcinomas (DTC), TSH act as a growth factor predominantly through interactions with the thyrotropin receptor on papillary and follicular thyroid cancer cells. Thus, lowering or suppression of host TSH with exogenous $\mathrm{T}_{4}$ can be applied for standardized primary treatment and long-term management of DTC. On the other hand, $\mathrm{T}_{4}$ can also be used to suppress TSH in recurrent disease, supporting a critical role of $\mathrm{T}_{4}$ in modulating DTC proliferation and recurrence via influencing TSH [114]. In vitro findings suggest that treatment with external THs enhances proliferation of human papillary and follicular thyroid cancer cells. Specifically, THs interact with plasma membrane integrin $\alpha v \beta 3$, activating MAPK/ERK1/2 signaling and promoting papillary and follicular thyroid cancer cell proliferation and anti-apoptosis [79]. Additionally, experiments on a mouse model of thyroid carcinoma primary and metastatic lesions showed activation of PI3K-Akt signaling upon mutation of TR $\beta$. Thyroid hormone $\beta$ receptor (TR $\beta) P V / P V$ mice with knock-in mutant TR $\beta$ gene (TR $\beta P V$ mutant) spontaneously developed thyroid cancer and distant metastasis similar to human follicular thyroid cancer. Furthermore, in these spontaneous thyroid tumors, the ligand binding domain of TR interacted with PI3K regulatory subunit, p85 $\alpha$, to a greater extent than wild-type TR $\beta$. LY-294002 is a PI3K signaling specific inhibitor, which blocks rapamycin-p70(S6K) of Akt mammalian signaling, leading to both increased p27 and decreased cyclin D1, further inhibiting thyroid tumor growth and tumor cell proliferation. LY294002 treatment promotes thyroid tumor apoptosis by increasing caspase-3 expression and reducing phosphorylated BAD and suppresses thyroid cancer cell motility, thus influencing metastatic ability [80]. Data from this study suggest that mutation of TR $\beta$ plays a critical role in thyroid cancer development. In another study, a mouse model with dominant-negative mutant thyroid hormone receptor $\beta$ (denoted PV) was generated. Reduced PI3K activation by $\mathrm{T}_{3}$ in $\mathrm{Thrb}(\mathrm{PV} / \mathrm{PV})$ mice was observed, along with inability to bind to mutant TR $\beta$ under conditions of hypothyroidism [66]. The data suggest that thyroid gland carcinogenesis in Thrb(PV/PV) mice is promoted by thyroid hormone via binding to cell surface integrin $\alpha v \beta 3$ [66]. Deiodinase type 3 (DIO3, D3) that converts $\mathrm{T}_{4}$ to $\mathrm{T}_{3}$ is upregulated in the human PTC-derived cell line, K1, by transforming growth factor $\beta 1$ (TGF $\beta 1$ ). Additionally, treatment with the inhibitors U0126 (ERK pathway) and SB203580 (p38 pathway) led to blockage of the MAPK pathway, and subsequent decrease in DIO3 mRNA and inhibition of DIO3 transcriptional induction via TGF $\beta 1$, clearly suggesting that D3 is upregulated via MAPK signaling [115]. The collective findings indicate that D3 expression is positively correlated with thyroid tumor size and disease spread [115].

\subsection{Lung Cancer}

Around $60 \%$ of patients diagnosed with lung cancer present an advanced stage of disease that is too late for surgical treatment. Small-cell lung carcinoma is associated with symptoms of hyperthyroidism [116]. Lung cancer patients often present with non-thyroidal illness syndrome (NTIS) or sick euthyroid syndrome, characterized by alterations in circulating TH expression in acute or 
chronic systemic disease. In NTIS patients, the circulating $\mathrm{T}_{3}$ level is decreased and $\mathrm{T}_{4} / \mathrm{T}_{3}$ expression ratio significantly increased along with modest alterations in regulation of $\mathrm{rT}_{3}$. Over a six-month observation period, mortality of lung cancer patients with low-level $\mathrm{T}_{3}$ was higher than that of lung cancer patients with normal $\mathrm{T}_{3}$ expression [117]. In NTIS patients with both small cell and non-small cell cancer, $\mathrm{T}_{3}$ was associated with disease stage and served as a poor prognostic factor [118]. In the human non-small cell cancer cell lines NCI-H522 and NCI-H510A, $\mathrm{T}_{4}$ induced a significant increase in proliferating cell nuclear antigen (PCNA) as well as high concentrations of $\mathrm{T}_{3}$ [81]. These experiments suggest that high expression of $\mathrm{T}_{4}$ in ER $\alpha$-positive lung cancer cells induces phosphorylation of $\mathrm{ER} \alpha$ and activation of ERK1/2, further enhancing PCNA expression and proliferative activity. The collective findings indicate that $\mathrm{T}_{4}$ is correlated with lung cancer through inducing hyperthyroidism, which may be a potential risk factor. In an animal model of Lewis lung carcinoma (3LL), cell growth progression is associated with reduced $\mathrm{T}_{4}$ and $\mathrm{T}_{3}$ levels. Subcutaneous injection with $\mathrm{T}_{4}$ induces a hyperthyroid stage and further increase in $\mathrm{T}_{4}$ and $\mathrm{T}_{3}$ levels associated with primary tumor growth and development of pulmonary metastases 3LL cells. However, the functional effect of $\mathrm{T}_{3}$ on 3LL cells is distinct from that of $\mathrm{T}_{4}$, which induces significant inhibition of pulmonary metastases and prolongs mouse survival. Additionally, $\mathrm{THs}\left(\mathrm{T}_{4}\right.$ and $\left.\mathrm{T}_{3}\right)$ treatment promotes cytotoxicity against $3 \mathrm{LL}$ cells mediated by alveolar macrophages [119]. Alterations in THs expression influence against primary tumor formation and metastases of lung cancer in the natural host. In lung cancer, THs regulate tumor proliferation and activation of MAPK/ERK1/2 signaling via interactions with TRs on $\alpha v \beta 3$ integrin. Around $61 \%$ of small-cell lung cancer (SCLC) and $48 \%$ of non-SCLC (NSCLC) cases lack TR $\beta 1$ expression. While TR $\beta 1$ mutations are not commonly observed in human cancers, aberrant TR $\beta 1$ through epigenetic regulation has been reported. Neither SCLC nor NSCLC cell lines display somatic mutations of TR $\beta 1$. However, methylation of the TR $\beta 1$ promoter has been shown to induce significant loss of TR $\beta 1 \mathrm{mRNA}$ expression [120].

\subsection{Brain Tumors}

Clinical studies to date have reported extremely low survival rates of patients with glioblastoma multiforme (GBM), the most malignant brain tumor type, with the poorest prognosis. The hypothyroid overall survival rate is longer than that of euthyroid patients [73]. Experiments by another group demonstrated that THs stimulate glioblastoma cell proliferation. Similar to data obtained with other solid tumors, hypothyroidism is associated with improved duration of survival $[82,83]$. Studies on 230 patients with primary brain tumors showed that $27 \%$ had NTIS with high 5-year mortality and short overall survival [121,122]. Additionally, NTIS is a poor prognostic marker for patients undergoing brain tumor surgery. $T_{4}$ can further stimulate glioblastoma growth through interactions with integrin $\alpha v \beta 3$ in the cytoplasm [57,82-84]. Both $T_{4}$ and $T_{3}$ act as stimulators that induce proliferating cell nuclear antigen (PCNA) accumulation in glioma cells via activation of MAPK/ERK1/2. $\mathrm{T}_{3}$ induces PI3K activation, Src kinase and MAPK/ERK1/2 signaling in U-87MG cells. Stimulation of the PI3K pathway by $\mathrm{T}_{3}$ promotes TR $\beta$ translocation from the cytoplasm to nucleus and activation of HIF-1 $\alpha$ mRNA transcription [57]. Interestingly, TR $\alpha 1$ and TR $\alpha 2$ expression in human astrocytomas decrease while TR $\beta 1$ expression increases with grade of malignancy [85]. Additionally, in the human medulloblastoma cell line, HTB-185, increased TR $\alpha 2$ transcriptional activity is not accompanied by TR $\beta 2$ expression [123].

\subsection{Liver Cancer}

Hypothyroidism plays an important role in liver carcinogenesis. A previous study reported hypothyroidism over ten years in female patients with hepatocellular carcinoma, indicating a significant association of hypothyroidism with high risk of human hepatocellular carcinoma (HCC) in females independent of known risk factors [124]. Additional findings support the prevalence of hypothyroidism in HCC patients. The correlation between thyroid function and cancer risk in HCC is related to induction of TSH under the hypothyroid state. In HCC tissue, thyroid stimulating hormone receptor (TSHR) is overexpressed. Therefore, under a hypothyroid state, TSH secretion and synthesis are induced 
in response to increased binding with highly expressed TSHR and promote HCC progression [125]. A number of studies have demonstrated that $\mathrm{T}_{3}$ in HCC downregulates oncogenic CDK2, cyclin $\mathrm{E}$ and phospho- $\mathrm{Rb}$, upregulates the tumor suppressor p21 and further inhibits cancer cell proliferation [86,87]. Additionally, $\mathrm{T}_{3}$ inhibits cell invasion and metastatic potential via inducing DKK4 expression by reduction of matrix MMP2 and downregulation of the transcription factor ELF2 associated with tumor growth and cell proliferation [88,89]. In HCC tissue and HCC cell lines, both TR $\alpha$ and TR $\beta$ display high dominance of truncating and point mutations [126-128] Interestingly, v-erbA is not only an oncogene but also translates to a mutant form of TR $\alpha$. Oncogene activity is possibly stimulated in hepatocytes via $v$-erbA dominant-negative activity on $\mathrm{T}_{3}$-responsive genes [90]. The $v$-erbA dysregulated $\mathrm{T}_{3}$ responsive genes include follistatin, activin $\beta C$, thrombomodulin, Six1, Rasgrp3 and Ndrg2, which are involved in carcinogenesis leading to HCC development in a transgene mouse model [90]. An earlier study suggested that the v-erbA oncogene of avian erythroblastosis virus is devoid of ligand-binding ability. In transgenic mice expressing $v$-erbA, some abnormal physiological phenomena were observed, including breeding disorders, abnormal behavior, reduced adipose tissue, hypothyroidism with inappropriate TSH response and enlarged seminal vesicles. As stated above, earlier experiments supported the development of hepatocellular carcinoma in male animals via v-erbA modulation and further identified aberrant (or mutant) TR in correlation with carcinogenesis [129]. On the other hand, $\mathrm{T}_{3}$ is reported to be upregulated lipocalin 2 and promote HCC invasiveness by TRs. Additionally, in HCC patient samples, both lipocalin 2 and TR $\alpha$ are overexpressed, which are correlated with cancer grade, stage and survival [91]. $\mathrm{T}_{4}$ can activate NF- $\mathrm{B}$, which is required for THs to induce HCC self-renewal and increase cancer stem-like cells and drug resistance [92]. Finally, similar to other cancer types, $T_{3}$ induces HCC growth by activating ERK1/2/Akt signaling via binding to integrin $\alpha v \beta 3$ [93]. In mice, dependent on hyperthyroid conditions and expression of TR $\alpha 1$ in HCC cells, HCC invasion and metastasis are promoted through mediation of MET/FAK pathways. Simultaneously, clinical researchers have further confirmed that in human HCC, tissue samples highly express TR $\alpha 1$ in association with lower survival. To date, no significant correlation between TR $\beta 1$ and HCC clinical tissue sample has been established. However, in other HCC specimens, decreased expression of TRs (including TR $\alpha 1$ ) is reported, supporting a tumor suppressor role [94]. Thus, $\mathrm{T}_{3} / \mathrm{TR}$ may play a dual role (either as an oncogene or tumor suppressor), depending on the molecular background and disease stage. However, this hypothesis remains to be tested.

\subsection{Colorectal Cancer}

Significant clinical research has focused on colon cancer in addition to breast, prostate and lung cancer types. The pathogenesis rate of colon cancer has been shown to be increased by thyrotropin [72]. Data from the Molecular Epidemiology of Colorectal Cancer (MECC) study in Israel indicate that treatment with L-thyroxine for five years can reduce the risk of large bowel cancer [130]. In another study, patients with colorectal cancer displayed reduced $\mathrm{T}_{3}$ levels in plasma associated with systemic metastases, implying that inhibition of thyroid hormone signaling further suppresses colorectal cancer invasiveness [131]. This effect may be specifically associated with NTIS. A number of studies propose a possible link between colorectal cancer and thyroid hormone disorders, considering circulation of thyroid hormones, thyrotropin levels and duration of thyroid disease. An earlier investigation showed increased $\mathrm{rT}_{3}$ levels in plasma in $24 \%$ of colorectal cancer cases and elevated $\mathrm{rT}_{3} / \mathrm{T}_{3}$ ratio in patients with metastatic colorectal cancer [131]. In view of this finding, it is hypothesized that $\mathrm{rT}_{3}$ accumulates in metastatic colorectal cancer via deiodinase type $3\left(\mathrm{D}_{3}\right)$ activity, $\mathrm{D}_{3}$ converts $\mathrm{T}_{3}$ to $T_{2}$, thus attenuating $T_{3}$ action locally, and the $T_{4} / T_{3}$ ratio is increased, supporting a critical role of thyroid hormone in modulating colorectal cancer metastasis. The mechanism underlying polypoid growth of colorectal cancer remains unclear but may be associated with trophic stimuli, such as thyroid hormones. Colorectal cancer has a high level of integrin $\alpha v \beta 3$-expressing tumor vasculature and is associated with significantly lower relapse-free and overall survival, compared to that of patients with low integrin $\alpha \mathrm{v} \beta 3$ levels in tumor vasculature [132]. Based on these observations, it is proposed 
that thyroid hormones not only modulate colorectal cancer progression through cell surface integrin $\alpha v \beta 3$ but also that integrin $\alpha v \beta 3$ acts as a prognostic indicator of colon carcinoma [132]. Colorectal cancer proliferation is induced by $\mathrm{T}_{4}$ and thyroxine, both in vitro and in vivo, in a dose-dependent manner in HCT-116, HT-29 and Colo205 cell lines [95,96]. In addition, colorectal cancer progression is promoted through enhancing epithelial cell proliferation in the colon mucosa by $\mathrm{T}_{4}$ [133]. Treatment of thyroidectomized rats with $\mathrm{T}_{4}$ has been shown to enhance the number of cells per intestinal crypt, suggesting an important regulatory role in intestinal stem-progenitor cell proliferation. However, $\mathrm{T}_{4}$ only affects tumor cell proliferative activity and not the histological appearance of colorectal tumors and colon adenocarcinoma type and depth [134]. As stated above, deiodinase type $3\left(D_{3}\right)$ is also involved in colorectal cancer and reported to promote human colon adenoma and adenocarcinoma relative to healthy surrounding mucosa [97]. The $\beta$-catenin/T-cell factor complex activated in colorectal cancer stimulates $\mathrm{D}_{3}$ expression and $\mathrm{T}_{3}$-induced colorectal cancer cell proliferation. However, in both xenograft mice and colon cancer cells, knockdown of $\beta$-catenin either led to reduced cell proliferation or enhanced cell differentiation. Overexpression of TR $\alpha 1$ in intestinal cancers promotes hyperproliferation and accelerates the tumorigenic process both in vivo and in vitro [98]. Upon TR $\alpha 1$ overexpression in $\mathrm{Apc}^{+} / 1638 \mathrm{~N}$ mice, tumor appearance, metastasis and intestinal cancer progression are observed. In $\mathrm{Apc}^{+} / 1638 \mathrm{~N}$ mice overexpressing vil-TR $\alpha 1$ (intestinal epithelium-targeted overexpression of TR $\alpha 1$ ), the tumor development rate is higher than that in control Apc ${ }^{+} / 1638 \mathrm{~N}$ mice, suggesting that TR $\alpha 1$ is also involved in tumorigenesis via activation of $\beta$-catenin [98]. Wild-type TR $\alpha 1$ is beneficial for intestinal regeneration after $\gamma$-irradiation-induced DNA damage. However, mutation of TR $\alpha 1$ via irradiation neither induces apoptosis nor reduces cell proliferation. An animal model with the TR $\alpha 1$ mutation showed delayed p53 phosphorylation after induction of the DNA damage response. These experiments indicate that $\mathrm{TR} \alpha 1$ plays an important role in intestinal cancer progression via modulation of cell renewal and apoptosis after irradiation treatment and accumulation of DNA damage [135]. Additionally, $\mathrm{T}_{3}$ interacts with TR $\alpha 1$ via activation of Frizzled-related protein, sFRP2, which directly modulates $\beta$-catenin expression, a major regulator of intestinal cell proliferation $[71,136]$. Other studies suggest that loss of TR $\beta 1$ promotes malignant transformation of human colon tumors. Conversely, overexpression of TR $\beta 1$ is associated with reduced invasive activity and consequent biopsies in patients with colorectal cancer [137].

\subsection{Thyroid Hormone Is Anti-Apoptosis in Cancer Cells}

Previous studies reported that thyroid hormone not only play a key role to promote cancer cells proliferation but also induces anti-apoptosis. In breast cancer, the transcription of the pro-apoptotic Bcl-2-associated death promoter (Bad) gene and X-linked inhibitor of apoptosis (XIAP) gene are downregulated by $\mathrm{T}_{3}$. Additionally, both $\mathrm{T}_{3}$ and $\mathrm{T}_{4}$ not only decrease some of the pro-apoptosis markers including caspase-3, Bax but also increase expression of XIAP [63]. The action of $\mathrm{T}_{3}$ in the human glioblastoma U-87 MG cells accumulate hypoxia-inducible factor (HIF)-1 $\alpha$ mRNA (Figure 5A), which has anti-apoptosis function of gene, via activation of the PI3K pathway by $\alpha \mathrm{v} \beta 3$ [57]. Under the condition of $T_{3}$, the human kidney showed an increase in the myeloid cell leukemia-1 (MCL-1) transcription activity, which is an anti-apoptotic member of Bcl-2 family, via the presence of TR $\beta$ to prevent the formation of channels to release mitochondrial cytochrome $\mathrm{c}$ and induce apoptosis [138]. As stated above, we know that most THs promote cancer progression via activation of the signal transduction pathway, one is the MAPK/ERK1/2. Therefore, an ERK1/2 inhibitor, PD98059, which inhibits cascade of MAPK/ERK1/2 signaling transduction and further blocks thyroid hormone-induced cell proliferation [139]. In addition, resveratrol can activate ERK1/2 and induce accumulation of nuclear cyclooxygenase (COX-2) via directing interaction with the integrin $\alpha \mathrm{v} \beta 3$ receptor to further induce phosphorylation of ERK1/2, which translocates into the cell nucleus and complexes with inducible COX-2 in resveratrol treatment cancer cells. Immediately, the induction of p53-Ser15 phosphorylation can promote downstream gene expression including c-fos, c-jun, and p21 gene expression, and further induce cancer cell apoptosis. However, the action of $\mathrm{T}_{4}$ prevents p53-Ser15 phosphorylation and blocks 
induction cancer cell apoptosis [139]. These results strongly suggest that the thyroid hormone has anti-apoptosis function.
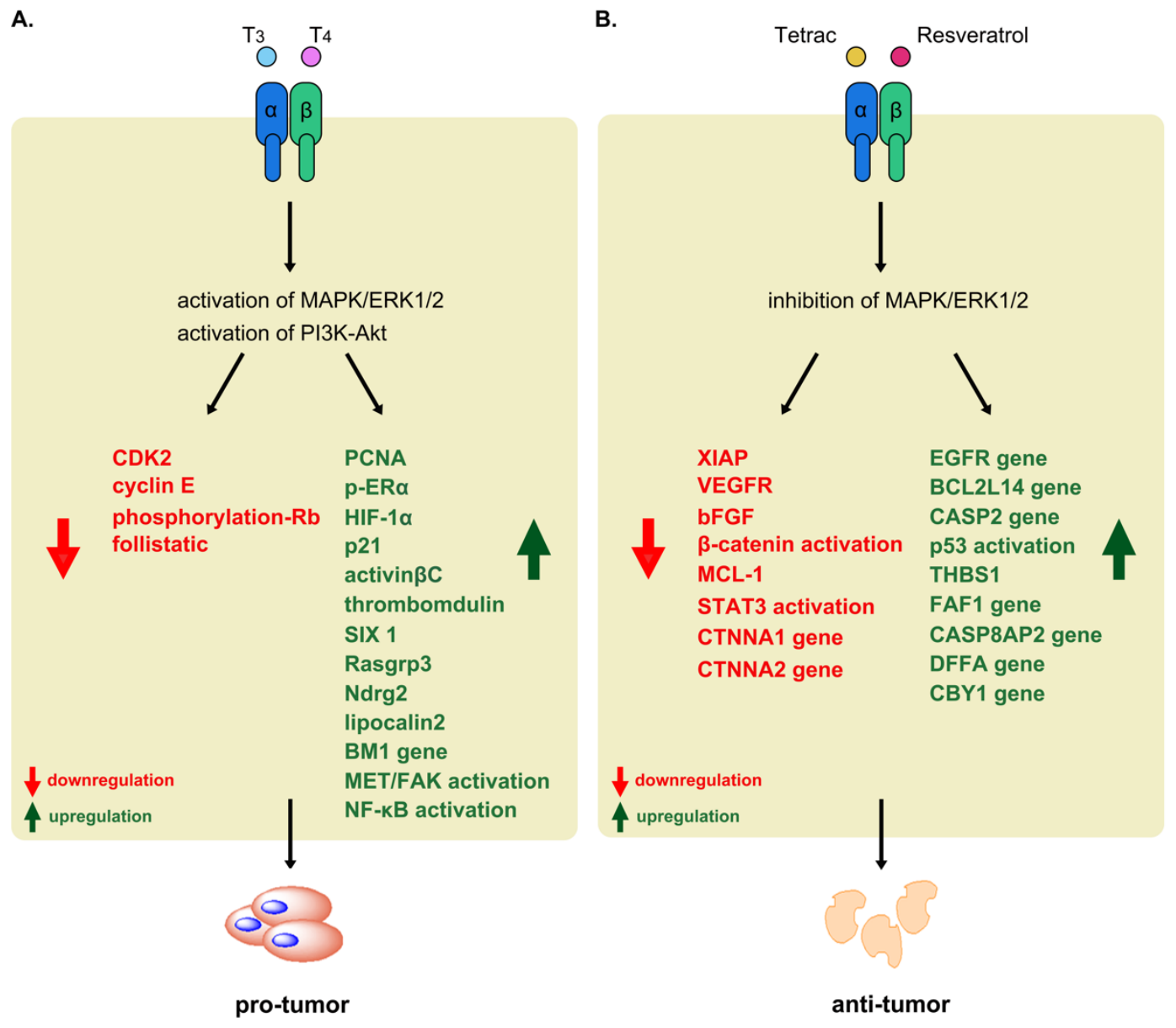

Figure 5. Non-genomic effects of pro-tumorigenic and anti-tumorigenic activities of thyroid hormones in tumor settings. (A) $\alpha \mathrm{v} \beta 3$ that binds both $\mathrm{T}_{3}$ and $\mathrm{T}_{4}$, leading to activation of MAPK/ERK1/2 and PI3K-Akt, inducing of PCNA, HIF-1 $\alpha$, P21, activin $\beta C$, thrombomodulin, SIX1 Rasgrp3, Ndrg2, lipocalin2 and BM1 gene expression to promote phosphorylation of ER $\alpha$, and activation of MET/FAK, $\mathrm{NF}-\mathrm{kB}$, and downregulation of CDK2, cyclin E, phosphorylation of Rb and follistatin, respectively. (B) Tetrac can inhibit $\mathrm{T}_{4}$ and $\mathrm{T}_{3}$ interactions with the cell surface receptor site of integrin $\alpha \mathrm{v} \beta 3$ and blocks TH-mediated activation of MAPK/ERK1/2 by principal iodothyronines. Tetrac and resveratrol compete with the binding site on integrin $\alpha \mathrm{v} \beta 3$, leading to blockage of cancer cell responses to $\mathrm{TH}$, leading to upregulation of mRNA of EGFR, BCL2L14, CASP2, FAF1, CASP8AP2, DFFA, CBY1, p53 and TSBH1. Conversely, they downregulate CTNNA1, CTNNA2, XIAP, VEGFR, bFGF mRNA expression as well as inhibit $\beta$-catenin and STAT3 activation.

\section{TH Analogs Exert Anti-Proliferative Effects on Cancer Cells}

Cancer cells display enhanced proliferation, reduced apoptosis and increased angiogenesis owing to both genomic and non-genomic actions of THs [140-142]. L-thyroxine $\left(\mathrm{T}_{4}\right)$ is the primary thyroid hormone produced by the thyroid gland, which generates $T_{3}$ via outer thyroid hormone ring deiodination at the $5^{\prime}$ position of the diphenyl ether structure of iodothyronines [143]. An alanine side-chain modification of iodothyronine occurs at the cellular level to further generate tetraiodothyroacetic acid (Tetrac) and triiodothyroacetic acid (Triac), both of which have metabolic activities [144]. Accumulating studies have demonstrated the presence of a receptor that can bind thyroid hormone analogs on the plasma membrane of multiple cancer types and rapidly divide 
endothelial cells $[3,51,107]$, and focused on determining the functions of thyroid hormone analogs. TH derivatives have been effectively utilized to distinguish beneficial actions or deleterious effects of THs for potential therapeutic application [145-148].

\subsection{Tetraiodothyroacetic Acid (Tetrac)}

Tetraiodothyroacetic acid (Tetrac) is an iodothyronine analog that inhibits $\mathrm{T}_{4}$ and $\mathrm{T}_{3}$ interactions with the cell surface receptor site of integrin $\alpha \mathrm{v} \beta 3$ and blocks TH-mediated activation of MAPK/ERK1/2 by principal iodothyronines. Tetrac competes with the binding site on integrin $\alpha v \beta 3$, leading to blockage of cancer cell responses to TH. In addition, in the absence of $\mathrm{T}_{4}$ and $\mathrm{T}_{3}$, Tetrac can influence regulated coherent activities with induction of cell death, modulating the cancer cell survival pathway. Tetrac prevents the activity of $\mathrm{T}_{4}$, thus restoring p53-dependent proapoptotic properties of cancer cells [79]. However, in the absence of $\mathrm{T}_{4}$, Tetrac does not influence the activity of stilbene resveratrol, which initiates p53-dependent apoptosis through integrin $\alpha v \beta 3$ in cancer cells [84]. Additionally, exposure of the estrogen receptor-negative human breast cancer cell line, MDA-MB-231, and medullary thyroid cancer cells, to unmodified Tetrac and nanoparticulate Tetrac (Nanotetrac), which is specifically covalently bound, revealed differential involvement in cancer survival and apoptosis pathways based on effects on gene transcription determined via microarray $[149,150]$. Tetrac treatment of MDA-MB-231 cells led to both downregulation of the apoptosis inhibitor, XIAP, and increased levels of the angiogenesis inhibitor, thrombospondin 1 (THBS1). On the other hand, Tetrac induced a significant increase in FAF1, CASP8AP2, DFFA, and CASP2 mRNA levels and inhibition of the angiogenic and metastatic effects of vascular endothelial growth factor (VEGFR) and basic fibroblast growth factor (bFGF) in cancer [151,152] (Figure 5B). Moreover, increased levels of CBY1, which inhibits $\beta$-catenin function in the nucleus, were observed in the presence of Tetrac $[149,150]$. Tetrac could directly modulate $\beta$-catenin abundance in the cell through downregulation of CTNNA1 and CTNNA2 mRNA (Figure 5B). According to a number of earlier studies, $\beta$-catenins are involved in cell-cell adhesion. However, mutation and overexpression of $\beta$-catenins occur in various cancer types, including colorectal carcinoma and breast and ovarian cancers $[153,154]$. In addition, mutation of one of the catenin genes, CTNNA1, which functions as a tumor suppressor in normal conditions, leads to susceptibility to gastrointestinal tract cancers [155], and mutation of the other catenin gene, CTNNA2, is associated with tumor invasiveness [156]. Nanotetrac is excluded from the cell interior, and inhibits cancer cell proliferation induced by thyroid hormone more effectively than unmodified Tetrac [63]. mRNA expression of anti-apoptotic MCL-1 is reduced and apoptosis-promoting CASP2, BCL2L14, and EGFR levels increased by Nanotetrac [63] (Figure 5B). In particular, Nanotetrac downregulates nine genes involved in the cell cycle, one of which is cyclin-dependent kinase gene, along with $>20$ oncogenes, including Ras family members [63,149]. Nanotetrac also influences tumor invasion, angiogenesis, and metastasis via regulation of matrix metalloproteinase-2 (MMP-2) whose major function is blockage of STAT3 activation by the thyroid hormone [157-159] (Figure 5B). The collective studies to date indicate that Tetrac modulates a series of genes involved in cancer cell proliferation, apoptosis and angiogenesis via inhibition of $T_{4}$ and $T_{3}$ actions on integrin $\alpha v \beta 3$.

\subsection{Triiodothyroacetic Acid (Triac)}

Tetraiodothyroacetic acid (Tetrac) and 3,3',5-triiodothyroacetic acid (Triac), acetic acid analogs of THs, have similar structures with thyromimetic activity in the nucleus [160]. Earlier in vitro findings suggest that Triac binding affinity is better than that of $T_{3}$ for both normal TR $\alpha 1$ and TR $\beta$ ( three-fold) [161]. Studies on dominant-negative mutants of TR $\beta$ in cancer have confirmed that Triac is more powerful than $T_{3}$, i.e., Triac can overcome the dominant-negative effects of TR $\beta$ mutations [161]. Triac initiates apoptosis in human ovarian cancer cells via non-genomic actions through effects on integrin $\alpha v \beta 3$ and does not influence mitochondria in tumor cells [162]. Nevertheless, the mechanisms by which Triac modulates genomic effects within cancer cells remain to be established. Triac does not interact with genetically modified TR $\beta$. Genetically modified TR $\beta$ is trafficked between the 
cytoplasm and nucleus in cancer cells in the presence or absence of $T_{3}$ and Triac; models can detect endocrine-disrupting chemicals (EDCs) that are a major health concern [163]. Long-term studies using non-cancer cells [164] have shown that Triac binds TR and can be used to clinically treat some forms of thyroid hormone resistance (THS) due to hypersecretion of TSH through elevating transport across the plasma membrane of normal cells [165-175]. However, the majority of findings to date suggest a significant reduction in basal TRH-stimulated TSH levels and serum-free $\mathrm{T}_{4}$ and $\mathrm{T}_{3}$ levels. In normal and hypothyroid patients, treatment with Triac led to inhibition of TSH synthesis and secretion without inducing changes in peripheral tissue metabolic effects, such as weight, heart rate, reflex time or serum concentrations of cholesterol or triglycerides [175]. Triac modulates normal growth and bone maturation in children with peripheral thyrotoxic features (pituitary RTH (PRTH)) owing to genetic mutation of TR $\beta$ (TR $\beta 1$ ) at exon 10 position 1642 ( $C$ to $A$ ) that generates the amino acid codon change, P453T. TR $\beta 1$ mutation led to significantly reduced $\mathrm{T}_{3}$ binding affinity. However, upon long-term treatment with Triac, normal heart rate, neurological and clinical signs were maintained in children. These findings suggest that administration of long-term Triac therapy in childhood is safe and efficacious for PRTH [167]. However, no influence on thyroid hormone function after discontinuation of Triac was reported in a proportion of patients, leading to reservations on the specificity of the compound.

\section{Conclusions}

Interactions between nuclear receptors and corresponding ligands that elicit critical molecular pathways have been verified in both normal and cancer cells [4]. This review provides an overview on the individual mechanisms underlying physiological TH/TR-mediated regulation of different cancer types. TRs have been detected in the majority of organs. The mRNAs (THRA and THRB) of TRs generated via alternative splicing produce different isoforms that exert specific physiological effects on the organs [176-178]. Additionally, thyroid hormones and TRs play important regulatory roles in physiological processes via actions on intracellular and extracellular proteins and activate various genomic or non-genomic functions including cellular growth, embryonic development, differentiation, metabolism, and proliferation. In normal cells and tissues, both $\mathrm{T}_{4}$ and $\mathrm{T}_{3}$ modulate skeletal development, bone turnover and maintenance and metabolism of organs $[2,143]$. $\mathrm{T}_{4}$ is a potent thyroid hormone with proliferation-enhancing activity in cancer cells that interacts with $\alpha v \beta 3$ integrin, which may serve as a potential target for inhibition of cancer proliferation. $T_{4}-\alpha v \beta 3$ inhibitors are not particularly efficacious and currently under preclinical analysis for treatment of a few cancer types. However, when disruption of $\mathrm{TH}$ signaling induces downstream target gene dysregulation or dysfunction, several organ diseases are initiated. Clinical researchers have suggested that TH/TRs promote proliferation of multiple cancer types including breast cancer, thyroid cancer, lung cancer, brain tumor, liver cancer, and colorectal cancer. In epidemiologic analyses, the risk of ovarian cancer development was shown to be almost double in patients with a history of hyperthyroidism. Moreover, risk was increased about two-fold for patients with pancreatic and prostate cancer with a history of hyperthyroidism. Both hyperthyroidism and hypothyroidism are known to influence the physiological processes underlying cancer. THs stimulate tumor growth and metastasis in vivo while hypothyroidism may be associated with inhibition of tumor proliferation and development. These findings collectively suggest that induction of hyperthyroidism is associated with progression of multiple cancer types. However, cancer progression pathways present considerable variability and complexity, and therefore, therapy utilizing THs/TRs continues to present several unknown challenges. Additionally, THs have not yet been established as a clinical risk factor or prognostic factor for cancer, partly due to their involvement in numerous physiological mechanisms, leading to conflicting experimental data over several years of research. The finding that different TR isoforms are involved in various tumor types and stages of development supports a dual role of TRs in human cancers, either as an oncogene or a tumor suppressor. However, this hypothesis remains to be investigated in detail. Further studies are required to establish the specific functions of TH/TR in cancers of different molecular backgrounds and stages. 
Author Contributions: The conceptualization, Y.-C.L. and K.-H.L.; investigation, Y.-C.L.; writing-original draft preparation, Y.-C.L.; writing—review and editing, Y.-C.L. and K.-H.L.; visualization, Y.-C.L.; supervision, K.-H.L.; funding acquisition, C.-T.Y. and K.-H.L.

Funding: This research was funded by grants from Chang Gung Memorial Hospital, Taoyuan, Taiwan (CMRPD1G0421, CMRPD1G0422, CMRPD1G0423, CMRPD1J0051, NMRPD1G0941-1G0943, and NMRPD1G0951-1G0953 to K. H. Lin) and from the Ministry of Science and Technology of the Republic of China (MOST 106-2320-B-182-031-MY3 and 106-2320-B-182-032-MY3 to K.H. Lin). And The APC was funded by Chang Gung Memorial Hospital, Taoyuan, Taiwan.

Conflicts of Interest: The authors declare no conflict of interest.

\section{References}

1. Chi, H.C.; Chen, C.Y.; Tsai, M.M.; Tsai, C.Y.; Lin, K.H. Molecular functions of thyroid hormones and their clinical significance in liver-related diseases. Biomed. Res. Int. 2013, 2013, 601361. [CrossRef] [PubMed]

2. Bassett, J.H.; Williams, G.R. Role of Thyroid Hormones in Skeletal Development and Bone Maintenance. Endocr. Rev. 2016, 37, 135-187. [CrossRef] [PubMed]

3. Davis, P.J.; Goglia, F.; Leonard, J.L. Nongenomic actions of thyroid hormone. Nat. Rev. Endocrinol. 2016, 12, 111-121. [CrossRef] [PubMed]

4. Aranda, A.; Pascual, A. Nuclear hormone receptors and gene expression. Physiol. Rev. 2001, 81, 1269-1304. [CrossRef] [PubMed]

5. Chi, H.C.; Tsai, C.Y.; Tsai, M.M.; Yeh, C.T.; Lin, K.H. Molecular functions and clinical impact of thyroid hormone-triggered autophagy in liver-related diseases. J. Biomed. Sci. 2019, 26, 24. [CrossRef] [PubMed]

6. Davies, T.F.; Ando, T.; Lin, R.Y.; Tomer, Y.; Latif, R. Thyrotropin receptor-associated diseases: from adenomata to Graves disease. J. Clin. Invest. 2005, 115, 1972-1983. [CrossRef] [PubMed]

7. Visser, W.E.; Friesema, E.C.; Visser, T.J. Minireview: thyroid hormone transporters: the knowns and the unknowns. Mol. Endocrinol. 2011, 25, 1-14. [CrossRef] [PubMed]

8. Brix, K.; Fuhrer, D.; Biebermann, H. Molecules important for thyroid hormone synthesis and action - known facts and future perspectives. Thyroid Res. 2011, 4 (Suppl 1), S9. [CrossRef]

9. Friesema, E.C.; Jansen, J.; Jachtenberg, J.W.; Visser, W.E.; Kester, M.H.; Visser, T.J. Effective cellular uptake and efflux of thyroid hormone by human monocarboxylate transporter 10. Mol. Endocrinol. 2008, 22, 1357-1369. [CrossRef] [PubMed]

10. Bernal, J. Thyroid hormone receptors in brain development and function. Nat. Clin. Pract. Endocrinol. Metab. 2007, 3, 249-259. [CrossRef]

11. Bassett, J.H.; Williams, G.R. Critical role of the hypothalamic-pituitary-thyroid axis in bone. Bone 2008, 43, 418-426. [CrossRef] [PubMed]

12. Cheng, S.Y. Multiple mechanisms for regulation of the transcriptional activity of thyroid hormone receptors. Rev. Endocr. Metab. Disord. 2000, 1, 9-18. [CrossRef] [PubMed]

13. Larsen, P.R. Thyroid hormone analogs and metabolites: new applications for an old hormone? Nat. Clin. Pract. Endocrinol. Metab. 2009, 5, 1. [CrossRef] [PubMed]

14. Oppenheimer, J.H.; Schwartz, H.L.; Surks, M.I. Nuclear binding capacity appears to limit the hepatic response to L-triiodothyronine (T3). Endocr. Res. Commun. 1975, 2, 309-325. [CrossRef] [PubMed]

15. Yen, P.M. Physiological and molecular basis of thyroid hormone action. Physiol. Rev. 2001, 81, $1097-1142$. [CrossRef] [PubMed]

16. Shao, D.L.; Lazar, M.A. Modulating nuclear receptor function: may the phos be with you. J. Clin. Investig. 1999, 103, 1617-1618. [CrossRef] [PubMed]

17. Mitsuhashi, T.; Tennyson, G.E.; Nikodem, V.M. Alternative splicing generates messages encoding rat c-erbA proteins that do not bind thyroid hormone. Proc. Natl. Acad. Sci. USA 1988, 85, 5804-5808. [CrossRef]

18. Sakurai, A.; Nakai, A.; DeGroot, L.J. Expression of three forms of thyroid hormone receptor in human tissues. Mol. Endocrinol. 1989, 3, 392-399. [CrossRef]

19. Jones, I.; Ng, L.; Liu, H.; Forrest, D. An intron control region differentially regulates expression of thyroid hormone receptor beta2 in the cochlea, pituitary, and cone photoreceptors. Mol. Endocrinol. 2007, 21, 1108-1119. [CrossRef]

20. Williams, G.R. Cloning and characterization of two novel thyroid hormone receptor beta isoforms. Mol. Cell Biol. 2000, 20, 8329-8342. [CrossRef] 
21. Ying, H.; Suzuki, H.; Zhao, L.; Willingham, M.C.; Meltzer, P.; Cheng, S.Y. Mutant thyroid hormone receptor beta represses the expression and transcriptional activity of peroxisome proliferator-activated receptor gamma during thyroid carcinogenesis. Cancer Res. 2003, 63, 5274-5280. [PubMed]

22. Pascual, A.; Aranda, A. Thyroid hormone receptors, cell growth and differentiation. Biochim Biophys Acta 2013, 1830, 3908-3916. [CrossRef] [PubMed]

23. Perlmann, T.; Rangarajan, P.N.; Umesono, K.; Evans, R.M. Determinants for selective RAR and TR recognition of direct repeat HREs. Genes Dev. 1993, 7, 1411-1422. [CrossRef]

24. Yen, P.M.; Ikeda, M.; Wilcox, E.C.; Brubaker, J.H.; Spanjaard, R.A.; Sugawara, A.; Chin, W.W. Half-site arrangement of hybrid glucocorticoid and thyroid hormone response elements specifies thyroid hormone receptor complex binding to DNA and transcriptional activity. J. Biol. Chem. 1994, 269, 12704-12709.

25. Mangelsdorf, D.J.; Evans, R.M. The RXR heterodimers and orphan receptors. Cell 1995, 83, 841-850. [CrossRef]

26. Horlein, A.J.; Naar, A.M.; Heinzel, T.; Torchia, J.; Gloss, B.; Kurokawa, R.; Ryan, A.; Kamei, Y.; Soderstrom, M.; Glass, C.K. Ligand-independent repression by the thyroid hormone receptor mediated by a nuclear receptor co-repressor. Nature 1995, 377, 397-404. [CrossRef] [PubMed]

27. Perissi, V.; Staszewski, L.M.; McInerney, E.M.; Kurokawa, R.; Krones, A.; Rose, D.W.; Lambert, M.H.; Milburn, M.V.; Glass, C.K.; Rosenfeld, M.G. Molecular determinants of nuclear receptor-corepressor interaction. Genes Dev. 1999, 13, 3198-3208. [CrossRef]

28. Struhl, K. Histone acetylation and transcriptional regulatory mechanisms. Genes Dev. 1998, 12, 599-606. [CrossRef]

29. Tyler, J.K.; Kadonaga, J.T. The "dark side" of chromatin remodeling: repressive effects on transcription. Cell 1999, 99, 443-446. [CrossRef]

30. Knoepfler, P.S.; Eisenman, R.N. Sin meets NuRD and other tails of repression. Cell 1999, 99, 447-450. [CrossRef]

31. Heinzel, T.; Lavinsky, R.M.; Mullen, T.M.; Soderstrom, M.; Laherty, C.D.; Torchia, J.; Yang, W.M.; Brard, G.; Ngo, S.D.; Davie, J.R.; et al. A complex containing N-CoR, mSin3 and histone deacetylase mediates transcriptional repression. Nature 1997, 387, 43-48. [CrossRef] [PubMed]

32. Nagy, L.; Kao, H.Y.; Chakravarti, D.; Lin, R.J.; Hassig, C.A.; Ayer, D.E.; Schreiber, S.L.; Evans, R.M. Nuclear receptor repression mediated by a complex containing SMRT, mSin3A, and histone deacetylase. Cell 1997, 89, 373-380. [CrossRef]

33. Guenther, M.G.; Lane, W.S.; Fischle, W.; Verdin, E.; Lazar, M.A.; Shiekhattar, R. A core SMRT corepressor complex containing HDAC3 and TBL1, a WD40-repeat protein linked to deafness. Genes Dev. 2000, 14, 1048-1057. [PubMed]

34. Fondell, J.D.; Ge, H.; Roeder, R.G. Ligand induction of a transcriptionally active thyroid hormone receptor coactivator complex. Proc. Natl. Acad. Sci. USA 1996, 93, 8329-8333. [CrossRef] [PubMed]

35. Fondell, J.D.; Guermah, M.; Malik, S.; Roeder, R.G. Thyroid hormone receptor-associated proteins and general positive cofactors mediate thyroid hormone receptor function in the absence of the TATA box-binding protein-associated factors of TFIID. Proc. Natl. Acad. Sci. USA 1999, 96, 1959-1964. [CrossRef] [PubMed]

36. Chen, D.; Ma, H.; Hong, H.; Koh, S.S.; Huang, S.M.; Schurter, B.T.; Aswad, D.W.; Stallcup, M.R. Regulation of transcription by a protein methyltransferase. Science 1999, 284, 2174-2177. [CrossRef] [PubMed]

37. Onate, S.A.; Tsai, S.Y.; Tsai, M.J.; O’Malley, B.W. Sequence and characterization of a coactivator for the steroid hormone receptor superfamily. Science 1995, 270, 1354-1357. [CrossRef] [PubMed]

38. Webb, P.; Nguyen, P.; Shinsako, J.; Anderson, C.; Feng, W.; Nguyen, M.P.; Chen, D.; Huang, S.M.; Subramanian, S.; McKinerney, E.; et al. Estrogen receptor activation function 1 works by binding p160 coactivator proteins. Mol. Endocrinol. 1998, 12, 1605-1618. [CrossRef] [PubMed]

39. Leo, C.; Chen, J.D. The SRC family of nuclear receptor coactivators. Gene 2000, 245, 1-11. [CrossRef]

40. Heery, D.M.; Kalkhoven, E.; Hoare, S.; Parker, M.G. A signature motif in transcriptional co-activators mediates binding to nuclear receptors. Nature 1997, 387, 733-736. [CrossRef]

41. Leers, J.; Treuter, E.; Gustafsson, J.A. Mechanistic principles in NR box-dependent interaction between nuclear hormone receptors and the coactivator TIF2. Mol. Cell. Biol. 1998, 18, 6001-6013. [CrossRef] [PubMed] 
42. McInerney, E.M.; Rose, D.W.; Flynn, S.E.; Westin, S.; Mullen, T.M.; Krones, A.; Inostroza, J.; Torchia, J.; Nolte, R.T.; Assa-Munt, N.; et al. Determinants of coactivator LXXLL motif specificity in nuclear receptor transcriptional activation. Gene Dev. 1998, 12, 3357-3368. [CrossRef] [PubMed]

43. Chen, X.Y.; Ferrington, D.A.; Bigelow, D.J.; Michaelis, E.K. Protein half-lives of two subunits of an NMDA receptor-like complex, the 71-kDa glutamate-binding and the 80-kDa CPP-binding protein. Biochem. Bioph. Res. Co. 1997, 241, 132-135. [CrossRef] [PubMed]

44. Kamei, Y.; Xu, L.; Heinzel, T.; Torchia, J.; Kurokawa, R.; Gloss, B.; Lin, S.C.; Heyman, R.A.; Rose, D.W.; Glass, C.K.; et al. A CBP integrator complex mediates transcriptional activation and AP-1 inhibition by nuclear receptors. Cell 1996, 85, 403-414. [CrossRef]

45. McKenna, N.J.; Nawaz, Z.; Tsai, S.Y.; Tsai, M.J.; O’Malley, B.W. Distinct steady-state nuclear receptor coregulator complexes exist in vivo. Proc. Natl. Acad. Sci. USA 1998, 95, 11697-11702. [CrossRef] [PubMed]

46. Takeshita, T.; Arita, T.; Asao, H.; Tanaka, N.; Higuchi, M.; Kuroda, H.; Kaneko, K.; Munakata, H.; Endo, Y.; Fujita, T.; et al. Cloning of a novel signal-transducing adaptor molecule containing an SH3 domain and ITAM. Biochem. Bioph. Res. Co. 1996, 225, 1035-1039. [CrossRef] [PubMed]

47. Rachez, C.; Gamble, M.; Chang, C.P.; Atkins, G.B.; Lazar, M.A.; Freedman, L.P. The DRIP complex and SRC-1/p160 coactivators share similar nuclear receptor binding determinants but constitute functionally distinct complexes. Mol. Cell Biol. 2000, 20, 2718-2726. [CrossRef]

48. Llopis, J.; Westin, S.; Ricote, M.; Wang, Z.; Cho, C.Y.; Kurokawa, R.; Mullen, T.M.; Rose, D.W.; Rosenfeld, M.G.; Tsien, R.Y.; et al. Ligand-dependent interactions of coactivators steroid receptor coactivator-1 and peroxisome proliferator-activated receptor binding protein with nuclear hormone receptors can be imaged in live cells and are required for transcription. Proc. Natl. Acad. Sci. USA 2000, 97, 4363-4368. [CrossRef]

49. Siegrist-Kaiser, C.A.; Juge-Aubry, C.; Tranter, M.P.; Ekenbarger, D.M.; Leonard, J.L. Thyroxine-dependent modulation of actin polymerization in cultured astrocytes. A novel, extranuclear action of thyroid hormone. J. Biol. Chem. 1990, 265, 5296-5302.

50. Sterling, K.; Brenner, M.A.; Sakurada, T. Rapid effect of triiodothyronine on the mitochondrial pathway in rat liver in vivo. Science 1980, 210, 340-342. [CrossRef]

51. Bergh, J.J.; Lin, H.Y.; Lansing, L.; Mohamed, S.N.; Davis, F.B.; Mousa, S.; Davis, P.J. Integrin alphaVbeta3 contains a cell surface receptor site for thyroid hormone that is linked to activation of mitogen-activated protein kinase and induction of angiogenesis. Endocrinology 2005, 146, 2864-2871. [CrossRef] [PubMed]

52. Plow, E.F.; Haas, T.A.; Zhang, L.; Loftus, J.; Smith, J.W. Ligand binding to integrins. J. Biol. Chem. 2000, 275, 21785-21788. [CrossRef] [PubMed]

53. Lin, H.Y.; Cody, V.; Davis, F.B.; Hercbergs, A.A.; Luidens, M.K.; Mousa, S.A.; Davis, P.J. Identification and functions of the plasma membrane receptor for thyroid hormone analogues. Discov Med. 2011, 11, 337-347. [PubMed]

54. Davis, P.J.; Davis, F.B.; Mousa, S.A.; Luidens, M.K.; Lin, H.Y. Membrane receptor for thyroid hormone: physiologic and pharmacologic implications. Annu. Rev. Pharmacol. Toxicol. 2011, 51, 99-115. [CrossRef] [PubMed]

55. Lin, H.Y.; Shih, A.; Davis, F.B.; Davis, P.J. Thyroid hormone promotes the phosphorylation of STAT3 and potentiates the action of epidermal growth factor in cultured cells. Biochem J. 1999, 338 Pt 2, 427-432. [CrossRef]

56. Cao, H.J.; Lin, H.Y.; Luidens, M.K.; Davis, F.B.; Davis, P.J. Cytoplasm-to-nucleus shuttling of thyroid hormone receptor-beta1 (Trbeta1) is directed from a plasma membrane integrin receptor by thyroid hormone. Endocr. Res. 2009, 34, 31-42. [CrossRef] [PubMed]

57. Lin, H.Y.; Sun, M.; Tang, H.Y.; Lin, C.; Luidens, M.K.; Mousa, S.A.; Incerpi, S.; Drusano, G.L.; Davis, F.B.; Davis, P.J. L-Thyroxine vs. 3,5,3'-triiodo-L-thyronine and cell proliferation: activation of mitogen-activated protein kinase and phosphatidylinositol 3-kinase. Am. J. Physiol. Cell Physiol. 2009, 296, C980-C991. [CrossRef] [PubMed]

58. Davis, P.J.; Lin, H.Y.; Mousa, S.A.; Luidens, M.K.; Hercbergs, A.A.; Wehling, M.; Davis, F.B. Overlapping nongenomic and genomic actions of thyroid hormone and steroids. Steroids 2011, 76, 829-833. [CrossRef] [PubMed]

59. Cao, X.; Kambe, F.; Moeller, L.C.; Refetoff, S.; Seo, H. Thyroid hormone induces rapid activation of Akt/protein kinase B-mammalian target of rapamycin-p70S6K cascade through phosphatidylinositol 3-kinase in human fibroblasts. Mol. Endocrinol. 2005, 19, 102-112. [CrossRef] [PubMed] 
60. Moeller, L.C.; Cao, X.; Dumitrescu, A.M.; Seo, H.; Refetoff, S. Thyroid hormone mediated changes in gene expression can be initiated by cytosolic action of the thyroid hormone receptor beta through the phosphatidylinositol 3-kinase pathway. Nucl. Recept. Signal. 2006, 4, e020. [CrossRef] [PubMed]

61. Moeller, L.C.; Dumitrescu, A.M.; Refetoff, S. Cytosolic action of thyroid hormone leads to induction of hypoxia-inducible factor-1alpha and glycolytic genes. Mol. Endocrinol 2005, 19, 2955-2963. [CrossRef] [PubMed]

62. Bhargava, M.; Lei, J.; Ingbar, D.H. Nongenomic actions of L-thyroxine and 3,5,3'-triiodo-L-thyronine. Focus on "L-Thyroxine vs. 3,5,3'-triiodo-L-thyronine and cell proliferation: Activation of mitogen-activated protein kinase and phosphatidylinositol 3-kinase". Am. J. Physiol. Cell Physiol. 2009, 296, C977-C979. [CrossRef] [PubMed]

63. Davis, P.J.; Glinsky, G.V.; Lin, H.Y.; Leith, J.T.; Hercbergs, A.; Tang, H.Y.; Ashur-Fabian, O.; Incerpi, S.; Mousa, S.A. Cancer Cell Gene Expression Modulated from Plasma Membrane Integrin alphavbeta3 by Thyroid Hormone and Nanoparticulate Tetrac. Front. Endocrinol. (Lausanne) 2014, 5, 240. [CrossRef] [PubMed]

64. Wang, C.S.; Lin, K.H.; Hsu, Y.C. Alterations of thyroid hormone receptor alpha gene: frequency and association with $\mathrm{Nm} 23$ protein expression and metastasis in gastric cancer. Cancer Lett. 2002, 175, 121-127. [CrossRef]

65. Lu, C.; Mishra, A.; Zhu, Y.J.; Meltzer, P.; Cheng, S.Y. Global expression profiling reveals gain-of-function oncogenic activity of a mutated thyroid hormone receptor in thyroid carcinogenesis. Am. J. Cancer Res. 2011, 1, 168-191. [PubMed]

66. Lu, C.; Zhu, X.; Willingham, M.C.; Cheng, S.Y. Activation of tumor cell proliferation by thyroid hormone in a mouse model of follicular thyroid carcinoma. Oncogene 2012, 31, 2007-2016. [CrossRef] [PubMed]

67. Park, J.W.; Zhao, L.; Cheng, S.Y. Inhibition of estrogen-dependent tumorigenesis by the thyroid hormone receptor beta in xenograft models. Am. J. Cancer Res. 2013, 3, 302-311.

68. Lin, K.H.; Zhu, X.G.; Shieh, H.Y.; Hsu, H.C.; Chen, S.T.; McPhie, P.; Cheng, S.Y. Identification of naturally occurring dominant negative mutants of thyroid hormone alpha 1 and beta 1 receptors in a human hepatocellular carcinoma cell line. Endocrinology 1996, 137, 4073-4081. [CrossRef]

69. Kamiya, Y.; Puzianowska-Kuznicka, M.; McPhie, P.; Nauman, J.; Cheng, S.Y.; Nauman, A. Expression of mutant thyroid hormone nuclear receptors is associated with human renal clear cell carcinoma. Carcinogenesis 2002, 23, 25-33. [CrossRef]

70. Heublein, S.; Mayr, D.; Meindl, A.; Angele, M.; Gallwas, J.; Jeschke, U.; Ditsch, N. Thyroid Hormone Receptors Predict Prognosis in BRCA1 Associated Breast Cancer in Opposing Ways. PloS ONE 2015, 10. [CrossRef]

71. Plateroti, M.; Kress, E.; Mori, J.I.; Samarut, J. Thyroid hormone receptor alpha1 directly controls transcription of the beta-catenin gene in intestinal epithelial cells. Mol. Cell Biol. 2006, 26, 3204-3214. [CrossRef] [PubMed]

72. Hellevik, A.I.; Asvold, B.O.; Bjoro, T.; Romundstad, P.R.; Nilsen, T.I.; Vatten, L.J. Thyroid function and cancer risk: a prospective population study. Cancer Epidemiol. Biomarkers Prev. 2009, 18, 570-574. [CrossRef] [PubMed]

73. Moeller, L.C.; Fuhrer, D. Thyroid hormone, thyroid hormone receptors, and cancer: a clinical perspective. Endocr. Relat. Cancer 2013, 20, R19-R29. [CrossRef] [PubMed]

74. Cristofanilli, M.; Yamamura, Y.; Kau, S.W.; Bevers, T.; Strom, S.; Patangan, M.; Hsu, L.; Krishnamurthy, S.; Theriault, R.L.; Hortobagyi, G.N. Thyroid hormone and breast carcinoma. Primary hypothyroidism is associated with a reduced incidence of primary breast carcinoma. Cancer-Am. Cancer Soc. 2005, 103, 1122-1128. [CrossRef]

75. Tang, H.Y.; Lin, H.Y.; Zhang, S.; Davis, F.B.; Davis, P.J. Thyroid hormone causes mitogen-activated protein kinase-dependent phosphorylation of the nuclear estrogen receptor. Endocrinology 2004, 145, 3265-3272. [CrossRef] [PubMed]

76. Sar, P.; Peter, R.; Rath, B.; Das Mohapatra, A.; Mishra, S.K. 3, 3'5 Triiodo L thyronine induces apoptosis in human breast cancer MCF-7 cells, repressing SMP30 expression through negative thyroid response elements. PLoS ONE 2011, 6, e20861. [CrossRef] [PubMed]

77. Gonzalez-Sancho, J.M.; Figueroa, A.; Lopez-Barahona, M.; Lopez, E.; Beug, H.; Munoz, A. Inhibition of proliferation and expression of T1 and cyclin D1 genes by thyroid hormone in mammary epithelial cells. Mol. Carcinog. 2002, 34, 25-34. [CrossRef] [PubMed] 
78. Guigon, C.J.; Kim, D.W.; Willingham, M.C.; Cheng, S.Y. Mutation of thyroid hormone receptor-beta in mice predisposes to the development of mammary tumors. Oncogene 2011, 30, 3381-3390. [CrossRef]

79. Lin, H.Y.; Tang, H.Y.; Shih, A.; Keating, T.; Cao, G.; Davis, P.J.; Davis, F.B. Thyroid hormone is a MAPK-dependent growth factor for thyroid cancer cells and is anti-apoptotic. Steroids 2007, 72, 180-187. [CrossRef]

80. Furuya, F.; Lu, C.; Willingham, M.C.; Cheng, S.Y. Inhibition of phosphatidylinositol 3-kinase delays tumor progression and blocks metastatic spread in a mouse model of thyroid cancer. Carcinogenesis 2007, 28, 2451-2458. [CrossRef]

81. Meng, R.; Tang, H.Y.; Westfall, J.; London, D.; Cao, J.H.; Mousa, S.A.; Luidens, M.; Hercbergs, A.; Davis, F.B.; Davis, P.J.; et al. Crosstalk between integrin alphavbeta3 and estrogen receptor-alpha is involved in thyroid hormone-induced proliferation in human lung carcinoma cells. PLoS ONE 2011, 6, e27547. [CrossRef] [PubMed]

82. Davis, F.B.; Tang, H.Y.; Shih, A.; Keating, T.; Lansing, L.; Hercbergs, A.; Fenstermaker, R.A.; Mousa, A.; Mousa, S.A.; Davis, P.J.; et al. Acting via a cell surface receptor, thyroid hormone is a growth factor for glioma cells. Cancer Res. 2006, 66, 7270-7275. [CrossRef] [PubMed]

83. Hercbergs, A.; Johnson, R.E.; Ashur-Fabian, O.; Garfield, D.H.; Davis, P.J. Medically induced euthyroid hypothyroxinemia may extend survival in compassionate need cancer patients: an observational study. Oncologist 2015, 20, 72-76. [CrossRef] [PubMed]

84. Lin, H.Y.; Tang, H.Y.; Keating, T.; Wu, Y.H.; Shih, A.; Hammond, D.; Sun, M.; Hercbergs, A.; Davis, F.B.; Davis, P.J. Resveratrol is pro-apoptotic and thyroid hormone is anti-apoptotic in glioma cells: both actions are integrin and ERK mediated. Carcinogenesis 2008, 29, 62-69. [CrossRef] [PubMed]

85. Hwang, S.L.; Lin, C.L.; Lieu, A.S.; Hwang, Y.F.; Howng, S.L.; Hong, Y.R.; Chang, D.S.; Lee, K.S. The expression of thyroid hormone receptor isoforms in human astrocytomas. Surg. Neurol. 2008, 70 (Suppl 1), S4-S8, discussion S1:8. [CrossRef] [PubMed]

86. Yen, C.C.; Huang, Y.H.; Liao, C.Y.; Liao, C.J.; Cheng, W.L.; Chen, W.J.; Lin, K.H. Mediation of the inhibitory effect of thyroid hormone on proliferation of hepatoma cells by transforming growth factor-beta. J. Mol. Endocrinol. 2006, 36, 9-21. [CrossRef] [PubMed]

87. Lin, Y.H.; Huang, Y.H.; Wu, M.H.; Wu, S.M.; Chi, H.C.; Liao, C.J.; Chen, C.Y.; Tseng, Y.H.; Tsai, C.Y.; Tsai, M.M.; et al. Thyroid hormone suppresses cell proliferation through endoglin-mediated promotion of p21 stability. Oncogene 2013, 32, 3904-3914. [CrossRef]

88. Mishkin, S.Y.; Pollack, R.; Yalovsky, M.A.; Morris, H.P.; Mishkin, S. Inhibition of local and metastatic hepatoma growth and prolongation of survival after induction of hypothyroidism. Cancer Res. 1981, 41, 3040-3045.

89. Chi, H.C.; Liao, C.H.; Huang, Y.H.; Wu, S.M.; Tsai, C.Y.; Liao, C.J.; Tseng, Y.H.; Lin, Y.H.; Chen, C.Y.; Chung, I.H.; et al. Thyroid hormone receptor inhibits hepatoma cell migration through transcriptional activation of Dickkopf 4. Biochem. Biophys. Res. Commun. 2013,439, 60-65. [CrossRef]

90. Ventura-Holman, T.; Mamoon, A.; Subauste, M.C.; Subauste, J.S. The effect of oncoprotein v-erbA on thyroid hormone-regulated genes in hepatocytes and their potential role in hepatocellular carcinoma. Mol. Biol. Rep. 2011, 38, 1137-1144. [CrossRef]

91. Chung, I.H.; Chen, C.Y.; Lin, Y.H.; Chi, H.C.; Huang, Y.H.; Tai, P.J.; Liao, C.J.; Tsai, C.Y.; Lin, S.L.; Wu, M.H.; et al. Thyroid hormone-mediated regulation of lipocalin 2 through the Met/FAK pathway in liver cancer. Oncotarget 2015, 6, 15050-15064. [CrossRef] [PubMed]

92. Wang, T.; Xia, L.; Ma, S.; Qi, X.; Li, Q.; Xia, Y.; Tang, X.; Cui, D.; Wang, Z.; Chi, J.; et al. Hepatocellular carcinoma: thyroid hormone promotes tumorigenicity through inducing cancer stem-like cell self-renewal. Sci. Rep. 2016, 6, 25183. [CrossRef] [PubMed]

93. Gnoni, G.V.; Rochira, A.; Leone, A.; Damiano, F.; Marsigliante, S.; Siculella, L. 3,5,3'triiodo-L-thyronine induces SREBP-1 expression by non-genomic actions in human HEP G2 cells. J. Cell Physiol. 2012, 227, 2388-2397. [CrossRef] [PubMed]

94. Liao, C.H.; Yeh, C.T.; Huang, Y.H.; Wu, S.M.; Chi, H.C.; Tsai, M.M.; Tsai, C.Y.; Liao, C.J.; Tseng, Y.H.; Lin, Y.H.; et al. Dickkopf 4 positively regulated by the thyroid hormone receptor suppresses cell invasion in human hepatoma cells. Hepatology 2012, 55, 910-920. [CrossRef] [PubMed] 
95. Chin, Y.T.; Hsieh, M.T.; Yang, S.H.; Tsai, P.W.; Wang, S.H.; Wang, C.C.; Lee, Y.S.; Cheng, G.Y.; HuangFu, W.C.; London, D.; et al. Anti-proliferative and gene expression actions of resveratrol in breast cancer cells in vitro. Oncotarget 2014, 5, 12891-12907. [CrossRef] [PubMed]

96. Lee, Y.S.; Chin, Y.T.; Yang, Y.S.H.; Wei, P.L.; Wu, H.C.; Shih, A.; Lu, Y.T.; Pedersen, J.Z.; Incerpi, S.; Liu, L.F.; et al. The combination of tetraiodothyroacetic acid and cetuximab inhibits cell proliferation in colorectal cancers with different K-ras status. Steroids 2016, 111, 63-70. [CrossRef] [PubMed]

97. Dentice, M.; Luongo, C.; Ambrosio, R.; Sibilio, A.; Casillo, A.; Iaccarino, A.; Troncone, G.; Fenzi, G.; Larsen, P.R.; Salvatore, D. beta-Catenin regulates deiodinase levels and thyroid hormone signaling in colon cancer cells. Gastroenterology 2012, 143, 1037-1047. [CrossRef] [PubMed]

98. Kress, E.; Skah, S.; Sirakov, M.; Nadjar, J.; Gadot, N.; Scoazec, J.Y.; Samarut, J.; Plateroti, M. Cooperation between the thyroid hormone receptor TRalpha1 and the WNT pathway in the induction of intestinal tumorigenesis. Gastroenterology 2010, 138, 1863-1874. [CrossRef]

99. Glushakov, R.I.; Proshin, S.N.; Tapil'skaya, N.I. The incidence of breast tumor during experimental hyperthyroidism. Bull. Exp. Biol Med. 2013, 156, 245-247. [CrossRef]

100. Conde, S.J.; Luvizotto Rde, A.; de Sibio, M.T.; Nogueira, C.R. Thyroid hormone status interferes with estrogen target gene expression in breast cancer samples in menopausal women. ISRN Endocrinol. 2014, 2014, 317398. [CrossRef] [PubMed]

101. Saraiva, P.P.; Figueiredo, N.B.; Padovani, C.R.; Brentani, M.M.; Nogueira, C.R. Profile of thyroid hormones in breast cancer patients. Braz. J. Med. Biol. Res. 2005, 38, 761-765. [CrossRef]

102. Lopez-Fontana, C.M.; Sasso, C.V.; Maselli, M.E.; Santiano, F.E.; Semino, S.N.; Cuello Carrion, F.D.; Jahn, G.A.; Caron, R.W. Experimental hypothyroidism increases apoptosis in dimethylbenzanthracene-induced mammary tumors. Oncol. Rep. 2013, 30, 1651-1660. [CrossRef]

103. Huang, J.; Jin, L.; Ji, G.; Xing, L.; Xu, C.; Xiong, X.; Li, H.; Wu, K.; Ren, G.; Kong, L. Implication from thyroid function decreasing during chemotherapy in breast cancer patients: chemosensitization role of triiodothyronine. BMC Cancer 2013, 13, 334. [CrossRef] [PubMed]

104. Dinda, S.; Sanchez, A.; Moudgil, V. Estrogen-like effects of thyroid hormone on the regulation of tumor suppressor proteins, p53 and retinoblastoma, in breast cancer cells. Oncogene 2002, 21, 761-768. [CrossRef] [PubMed]

105. Hall, L.C.; Salazar, E.P.; Kane, S.R.; Liu, N. Effects of thyroid hormones on human breast cancer cell proliferation. J. Steroid Biochem. Mol. Biol. 2008, 109, 57-66. [CrossRef] [PubMed]

106. Shao, Z.M.; Sheikh, M.S.; Rishi, A.K.; Dawson, M.I.; Li, X.S.; Wilber, J.F.; Feng, P.; Fontana, J.A. Thyroid hormone enhancement of estradiol stimulation of breast carcinoma proliferation. Exp. Cell Res. 1995, 218, 1-8. [CrossRef]

107. Cheng, S.Y.; Leonard, J.L.; Davis, P.J. Molecular aspects of thyroid hormone actions. Endocr. Rev. 2010, 31, 139-170. [CrossRef]

108. Davis, F.B.; Mousa, S.A.; O'Connor, L.; Mohamed, S.; Lin, H.Y.; Cao, H.J.; Davis, P.J. Proangiogenic action of thyroid hormone is fibroblast growth factor-dependent and is initiated at the cell surface. Circ. Res. 2004, 94, 1500-1506. [CrossRef]

109. Lombardi, A.; Moreno, M.; de Lange, P.; Iossa, S.; Busiello, R.A.; Goglia, F. Regulation of skeletal muscle mitochondrial activity by thyroid hormones: focus on the "old" triiodothyronine and the "emerging" 3,5-diiodothyronine. Front. Physiol. 2015, 6, 237. [CrossRef]

110. Ditsch, N.; Toth, B.; Himsl, I.; Lenhard, M.; Ochsenkuhn, R.; Friese, K.; Mayr, D.; Jeschke, U. Thyroid hormone receptor (TR)alpha and TRbeta expression in breast cancer. Histol Histopathol 2013, 28, 227-237. [CrossRef]

111. Jerzak, K.J.; Cockburn, J.; Pond, G.R.; Pritchard, K.I.; Narod, S.A.; Dhesy-Thind, S.K.; Bane, A. Thyroid hormone receptor alpha in breast cancer: prognostic and therapeutic implications. Breast Cancer Res. Treat. 2015, 149, 293-301. [CrossRef] [PubMed]

112. Zarebczan, B.; Chen, H. Multi-targeted approach in the treatment of thyroid cancer. Minerva Chir. 2010, 65, 59-69. [PubMed]

113. Ocak, S.; Akten, A.O.; Tez, M. Thyroid cancer in hyperthyroid patients: is it different clinical entity? Endocr. Regul. 2014, 48, 65-68. [CrossRef] [PubMed]

114. Davis, P.J.; Hercbergs, A.; Luidens, M.K.; Lin, H.Y. Recurrence of differentiated thyroid carcinoma during full TSH suppression: is the tumor now thyroid hormone dependent? Horm. Cancer 2015, 6, 7-12. [CrossRef] [PubMed] 
115. Romitti, M.; Wajner, S.M.; Zennig, N.; Goemann, I.M.; Bueno, A.L.; Meyer, E.L.; Maia, A.L. Increased type 3 deiodinase expression in papillary thyroid carcinoma. Thyroid 2012, 22, 897-904. [CrossRef]

116. Faber, J.; Poulsen, S.; Iversen, P.; Kirkegaard, C. Thyroid hormone turnover in patients with small cell carcinoma of the lung. Acta Endocrinol. (Copenh) 1988, 118, 460-464. [CrossRef]

117. Ratcliffe, J.G.; Stack, B.H.; Burt, R.W.; Radcliffe, W.A.; Spilg, W.G.; Cuthbert, J.; Kennedy, R.S. Thyroid function in lung cancer. Br. Med. J. 1978, 1, 210-212. [CrossRef]

118. Yasar, Z.A.; Kirakli, C.; Yilmaz, U.; Ucar, Z.Z.; Talay, F. Can non-thyroid illness syndrome predict mortality in lung cancer patients? A prospective cohort study. Horm. Cancer 2014, 5, 240-246. [CrossRef]

119. Kinoshita, S.; Sone, S.; Yamashita, T.; Tsubura, E.; Ogura, T. Effects of experimental hyper- and hypothyroidism on natural defense activities against Lewis lung carcinoma and its spontaneous pulmonary metastases in C57BL/6 mice. Tokushima J. Exp. Med. 1991, 38, 25-35.

120. Iwasaki, Y.; Sunaga, N.; Tomizawa, Y.; Imai, H.; Iijima, H.; Yanagitani, N.; Horiguchi, K.; Yamada, M.; Mori, M. Epigenetic inactivation of the thyroid hormone receptor beta1 gene at 3p24.2 in lung cancer. Ann. Surg. Oncol. 2010, 17, 2222-2228. [CrossRef]

121. Bunevicius, A.; Deltuva, V.; Tamasauskas, S.; Tamasauskas, A.; Laws, E.R., Jr.; Bunevicius, R. Low triiodothyronine syndrome as a predictor of poor outcomes in patients undergoing brain tumor surgery: a pilot study: clinical article. J. Neurosurg. 2013, 118, 1279-1287. [CrossRef] [PubMed]

122. Bunevicius, A.; Deltuva, V.P.; Tamasauskas, S.; Smith, T.; Laws, E.R.; Bunevicius, R.; Iervasi, G.; Tamasauskas, A. Preoperative low tri-iodothyronine concentration is associated with worse health status and shorter five year survival of primary brain tumor patients. Oncotarget 2017, 8, 8648-8656. [CrossRef] [PubMed]

123. Monden, T.; Nakajima, Y.; Hashida, T.; Ishii, S.; Tomaru, T.; Shibusawa, N.; Hashimoto, K.; Satoh, T.; Yamada, M.; Mori, M.; et al. Expression of thyroid hormone receptor isoforms down-regulated by thyroid hormone in human medulloblastoma cells. Endocr. J. 2006, 53, 181-187. [CrossRef] [PubMed]

124. Hassan, M.M.; Kaseb, A.; Li, D.; Patt, Y.Z.; Vauthey, J.N.; Thomas, M.B.; Curley, S.A.; Spitz, M.R.; Sherman, S.I.; Abdalla, E.K.; et al. Association between hypothyroidism and hepatocellular carcinoma: a case-control study in the United States. Hepatology 2009, 49, 1563-1570. [CrossRef] [PubMed]

125. Shih, Y.L.; Huang, Y.H.; Lin, K.H.; Chu, Y.D.; Yeh, C.T. Identification of Functional Thyroid Stimulating Hormone Receptor and TSHR Gene Mutations in Hepatocellular Carcinoma. Anticancer Res. 2018, 38, 2793-2802. [CrossRef]

126. Chan, I.H.; Privalsky, M.L. Thyroid hormone receptors mutated in liver cancer function as distorted antimorphs. Oncogene 2006, 25, 3576-3588. [CrossRef] [PubMed]

127. Lin, K.H.; Shieh, H.Y.; Chen, S.L.; Hsu, H.C. Expression of mutant thyroid hormone nuclear receptors in human hepatocellular carcinoma cells. Mol. Carcinog. 1999, 26, 53-61. [CrossRef]

128. Lin, K.H.; Zhu, X.G.; Hsu, H.C.; Chen, S.L.; Shieh, H.Y.; Chen, S.T.; McPhie, P.; Cheng, S.Y. Dominant negative activity of mutant thyroid hormone alpha1 receptors from patients with hepatocellular carcinoma. Endocrinology 1997, 138, 5308-5315. [CrossRef] [PubMed]

129. Barlow, C.; Meister, B.; Lardelli, M.; Lendahl, U.; Vennstrom, B. Thyroid abnormalities and hepatocellular carcinoma in mice transgenic for v-erbA. EMBO J. 1994, 13, 4241-4250. [CrossRef]

130. Rennert, G.; Rennert, H.S.; Pinchev, M.; Gruber, S.B. A case-control study of levothyroxine and the risk of colorectal cancer. J. Natl. Cancer Inst. 2010, 102, 568-572. [CrossRef]

131. Rose, D.P.; Davis, T.E. Plasma thyronine levels in carcinoma of the breast and colon. Arch. Intern. Med. 1981, 141, 1161-1164. [CrossRef] [PubMed]

132. Vonlaufen, A.; Wiedle, G.; Borisch, B.; Birrer, S.; Luder, P.; Imhof, B.A. Integrin alpha(v)beta(3) expression in colon carcinoma correlates with survival. Mod. Pathol. 2001, 14, 1126-1132. [CrossRef] [PubMed]

133. Iishi, H.; Tatsuta, M.; Baba, M.; Okuda, S.; Taniguchi, H. Enhancement by thyroxine of experimental carcinogenesis induced in rat colon by azoxymethane. Int. J. Cancer 1992, 50, 974-976. [CrossRef] [PubMed]

134. Iishi, H.; Tatsuta, M.; Baba, M.; Taniguchi, H. Monoamine oxidase B inhibitor enhances experimental carcinogenesis in rat colon induced by azoxymethane. Cancer Lett. 1994, 76, 177-183. [CrossRef]

135. Kress, E.; Rezza, A.; Nadjar, J.; Samarut, J.; Plateroti, M. The thyroid hormone receptor-alpha (TRalpha) gene encoding TRalpha1 controls deoxyribonucleic acid damage-induced tissue repair. Mol. Endocrinol. 2008, 22, 47-55. [CrossRef]

136. Clevers, H. Wnt/beta-catenin signaling in development and disease. Cell 2006, 127, 469-480. [CrossRef] 
137. Markowitz, S.; Haut, M.; Stellato, T.; Gerbic, C.; Molkentin, K. Expression of the ErbA-beta class of thyroid hormone receptors is selectively lost in human colon carcinoma. J. Clin. Invest. 1989, 84, 1683-1687. [CrossRef]

138. Pietrzak, M.; Puzianowska-Kuznicka, M. Triiodothyronine utilizes phosphatidylinositol 3-kinase pathway to activate anti-apoptotic myeloid cell leukemia-1. J. Mol. Endocrinol. 2008, 41, 177-186. [CrossRef]

139. Ho, Y.; Lin, Y.S.; Liu, H.L.; Shih, Y.J.; Lin, S.Y.; Shih, A.; Chin, Y.T.; Chen, Y.R.; Lin, H.Y.; Davis, P.J. Biological Mechanisms by Which Antiproliferative Actions of Resveratrol Are Minimized. Nutrients 2017, 9, 1046. [CrossRef]

140. Mousa, S.A.; Lin, H.Y.; Tang, H.Y.; Hercbergs, A.; Luidens, M.K.; Davis, P.J. Modulation of angiogenesis by thyroid hormone and hormone analogues: implications for cancer management. Angiogenesis 2014, 17, 463-469. [CrossRef]

141. Lin, H.Y.; Chin, Y.T.; Yang, Y.C.; Lai, H.Y.; Wang-Peng, J.; Liu, L.F.; Tang, H.Y.; Davis, P.J. Thyroid Hormone, Cancer, and Apoptosis. Compr. Physiol. 2016, 6, 1221-1237. [CrossRef] [PubMed]

142. Davis, P.J.; Sudha, T.; Lin, H.Y.; Mousa, S.A. Thyroid Hormone, Hormone Analogs, and Angiogenesis. Compr. Physiol. 2015, 6, 353-362. [CrossRef] [PubMed]

143. Peeters, R.P.; Visser, T.J. Metabolism of Thyroid Hormone, Feingold, K.R., Anawalt, B., Boyce, A., Chrousos, G., Dungan, K., Grossman, A., Hershman, J.M., Kaltsas, G., Koch, C., Kopp, P., et al., Eds.; South Dartmouth, MA, USA, 2000.

144. Senese, R.; Cioffi, F.; de Lange, P.; Goglia, F.; Lanni, A. Thyroid: biological actions of 'nonclassical' thyroid hormones. J. Endocrinol. 2014, 221, R1-R12. [CrossRef] [PubMed]

145. Moreno, M.; de Lange, P.; Lombardi, A.; Silvestri, E.; Lanni, A.; Goglia, F. Metabolic effects of thyroid hormone derivatives. Thyroid 2008, 18, 239-253. [CrossRef] [PubMed]

146. Brenta, G.; Danzi, S.; Klein, I. Potential therapeutic applications of thyroid hormone analogs. Nat. Clin. Pract. Endocrinol. Metab. 2007, 3, 632-640. [CrossRef]

147. Webb, P. Selective activators of thyroid hormone receptors. Expert. Opin. Investig. Drugs 2004, 13, 489-500. [CrossRef]

148. Baxter, J.D.; Webb, P. Thyroid hormone mimetics: potential applications in atherosclerosis, obesity and type 2 diabetes. Nat. Rev. Drug Discov. 2009, 8, 308-320. [CrossRef]

149. Glinskii, A.B.; Glinsky, G.V.; Lin, H.Y.; Tang, H.Y.; Sun, M.; Davis, F.B.; Luidens, M.K.; Mousa, S.A.; Hercbergs, A.H.; Davis, P.J. Modification of survival pathway gene expression in human breast cancer cells by tetraiodothyroacetic acid (tetrac). Cell Cycle 2009, 8, 3562-3570. [CrossRef]

150. Yalcin, M.; Dyskin, E.; Lansing, L.; Bharali, D.J.; Mousa, S.S.; Bridoux, A.; Hercbergs, A.H.; Lin, H.Y.; Davis, F.B.; Glinsky, G.V.; et al. Tetraiodothyroacetic acid (tetrac) and nanoparticulate tetrac arrest growth of medullary carcinoma of the thyroid. J. Clin. Endocrinol. Metab. 2010, 95, 1972-1980. [CrossRef]

151. Davidson, B.; Berner, A.; Nesland, J.M.; Risberg, B.; Berner, H.S.; Trope, C.G.; Kristensen, G.B.; Bryne, M.; Ann Florenes, V. E-cadherin and alpha-, beta-, and gamma-catenin protein expression is up-regulated in ovarian carcinoma cells in serous effusions. J. Pathol. 2000, 192, 460-469. [CrossRef]

152. Imai, T.; Horiuchi, A.; Shiozawa, T.; Osada, R.; Kikuchi, N.; Ohira, S.; Oka, K.; Konishi, I. Elevated expression of E-cadherin and alpha-, beta-, and gamma-catenins in metastatic lesions compared with primary epithelial ovarian carcinomas. Hum. Pathol. 2004, 35, 1469-1476. [CrossRef] [PubMed]

153. King, T.D.; Suto, M.J.; Li, Y. The Wnt/beta-catenin signaling pathway: a potential therapeutic target in the treatment of triple negative breast cancer. J. Cell Biochem. 2012, 113, 13-18. [CrossRef] [PubMed]

154. White, B.D.; Chien, A.J.; Dawson, D.W. Dysregulation of Wnt/beta-catenin signaling in gastrointestinal cancers. Gastroenterology 2012, 142, 219-232. [CrossRef] [PubMed]

155. Debruyne, P.; Vermeulen, S.; Mareel, M. The role of the E-cadherin/catenin complex in gastrointestinal cancer. Acta Gastroenterol Belg 1999, 62, 393-402. [PubMed]

156. Fanjul-Fernandez, M.; Quesada, V.; Cabanillas, R.; Cadinanos, J.; Fontanil, T.; Obaya, A.; Ramsay, A.J.; Llorente, J.L.; Astudillo, A.; Cal, S.; et al. Cell-cell adhesion genes CTNNA2 and CTNNA3 are tumour suppressors frequently mutated in laryngeal carcinomas. Nat. Commun. 2013, 4, 2531. [CrossRef] [PubMed]

157. Chen, R.N.; Huang, Y.H.; Lin, Y.C.; Yeh, C.T.; Liang, Y.; Chen, S.L.; Lin, K.H. Thyroid hormone promotes cell invasion through activation of furin expression in human hepatoma cell lines. Endocrinology 2008, 149, 3817-3831. [CrossRef] [PubMed] 
158. de Franciscis, S.; Serra, R. Matrix metalloproteinases and endothelial dysfunction: The search for new prognostic markers and for new therapeutic targets for vascular wall imbalance. Thromb. Res. 2015, 136, 5-6. [CrossRef] [PubMed]

159. Xie, T.X.; Wei, D.; Liu, M.; Gao, A.C.; Ali-Osman, F.; Sawaya, R.; Huang, S. Stat3 activation regulates the expression of matrix metalloproteinase-2 and tumor invasion and metastasis. Oncogene 2004, 23, 3550-3560. [CrossRef]

160. Lu, C.; Cheng, S.Y. Extranuclear signaling of mutated thyroid hormone receptors in promoting metastatic spread in thyroid carcinogenesis. Steroids 2011, 76, 885-891. [CrossRef]

161. Takeda, T.; Suzuki, S.; Liu, R.T.; DeGroot, L.J. Triiodothyroacetic acid has unique potential for therapy of resistance to thyroid hormone. J. Clin. Endocrinol. Metab. 1995, 80, 2033-2040. [CrossRef]

162. Shinderman-Maman, E.; Cohen, K.; Moskovich, D.; Hercbergs, A.; Werner, H.; Davis, P.J.; Ellis, M.; Ashur-Fabian, $\mathrm{O}$. Thyroid hormones derivatives reduce proliferation and induce cell death and DNA damage in ovarian cancer. Sci. Rep. 2017, 7, 16475. [CrossRef] [PubMed]

163. Stavreva, D.A.; Varticovski, L.; Levkova, L.; George, A.A.; Davis, L.; Pegoraro, G.; Blazer, V.; Iwanowicz, L.; Hager, G.L. Novel cell-based assay for detection of thyroid receptor beta-interacting environmental contaminants. Toxicology 2016, 368-369, 69-79. [CrossRef] [PubMed]

164. Groeneweg, S.; Peeters, R.P.; Visser, T.J.; Visser, W.E. Triiodothyroacetic acid in health and disease. J. Endocrinol. 2017, 234, R99-R121. [CrossRef] [PubMed]

165. Kunitake, J.M.; Hartman, N.; Henson, L.C.; Lieberman, J.; Williams, D.E.; Wong, M.; Hershman, J.M. 3,5,3'-triiodothyroacetic acid therapy for thyroid hormone resistance. J. Clin. Endocrinol. Metab. 1989, 69, 461-466. [CrossRef] [PubMed]

166. Dulgeroff, A.J.; Geffner, M.E.; Koyal, S.N.; Wong, M.; Hershman, J.M. Bromocriptine and Triac therapy for hyperthyroidism due to pituitary resistance to thyroid hormone. J. Clin. Endocrinol. Metab. 1992, 75, 1071-1075. [CrossRef] [PubMed]

167. Radetti, G.; Persani, L.; Molinaro, G.; Mannavola, D.; Cortelazzi, D.; Chatterjee, V.K.; Beck-Peccoz, P. Clinical and hormonal outcome after two years of triiodothyroacetic acid treatment in a child with thyroid hormone resistance. Thyroid 1997, 7, 775-778. [CrossRef]

168. Salmela, P.I.; Wide, L.; Juustila, H.; Ruokonen, A. Effects of thyroid hormones (T4,T3), bromocriptine and Triac on inappropriate TSH hypersecretion. Clin. Endocrinol. (Oxf.) 1988, 28, 497-507. [CrossRef]

169. Torre, P.; Bertoli, M.; Di Giovanni, S.; Scommegna, S.; Conte, C.; Novelli, G.; Cianfarani, S. Endocrine and neuropsychological assessment in a child with a novel mutation of thyroid hormone receptor: response to 12-month triiodothyroacetic acid (TRIAC) therapy. J. Endocrinol. Invest. 2005, 28, 657-662. [CrossRef]

170. Rivolta, C.M.; Mallea Gil, M.S.; Ballarino, C.; Ridruejo, M.C.; Miguel, C.M.; Gimenez, S.B.; Bernacchi, S.S.; Targovnik, H.M. A novel 1297-1304delGCCTGCCA mutation in the exon 10 of the thyroid hormone receptor beta gene causes resistance to thyroid hormone. Mol. Diagn. 2004, 8, 163-169.

171. Darendeliler, F.; Bas, F. Successful therapy with 3,5,3'-triiodothyroacetic acid (TRIAC) in pituitary resistance to thyroid hormone. J. Pediatr. Endocrinol. Metab. 1997, 10, 535-538. [CrossRef]

172. Beck-Peccoz, P.; Piscitelli, G.; Cattaneo, M.G.; Faglia, G. Successful treatment of hyperthyroidism due to nonneoplastic pituitary TSH hypersecretion with 3,5,3'-triiodothyroacetic acid (TRIAC). J. Endocrinol. Invest. 1983, 6, 217-223. [CrossRef] [PubMed]

173. Beck-Peccoz, P.; Mariotti, S.; Guillausseau, P.J.; Medri, G.; Piscitelli, G.; Bertoli, A.; Barbarino, A.; Rondena, M.; Chanson, P.; Pinchera, A. Treatment of hyperthyroidism due to inappropriate secretion of thyrotropin with the somatostatin analog SMS 201-995. J. Clin. Endocrinol. Metab. 1989, 68, 208-214. [CrossRef] [PubMed]

174. Lind, P.; Eber, O. Treatment of inappropriate TSH secretion with Triac. Acta Med. Austriaca 1986, 13, $13-16$. [PubMed]

175. Medeiros-Neto, G.; Kallas, W.G.; Knobel, M.; Cavaliere, H.; Mattar, E. Triac (3,5,3'-triiodothyroacetic acid) partially inhibits the thyrotropin response to synthetic thyrotropin-releasing hormone in normal and thyroidectomized hypothyroid patients. J. Clin. Endocrinol. Metab. 1980, 50, 223-225. [CrossRef]

176. Falcone, M.; Miyamoto, T.; Fierro-Renoy, F.; Macchia, E.; DeGroot, L.J. Antipeptide polyclonal antibodies specifically recognize each human thyroid hormone receptor isoform. Endocrinology 1992, 131, 2419-2429. [CrossRef] 
177. Hodin, R.A.; Lazar, M.A.; Chin, W.W. Differential and tissue-specific regulation of the multiple rat c-erbA messenger RNA species by thyroid hormone. J. Clin. Invest. 1990, 85, 101-105. [CrossRef]

178. Strait, K.A.; Schwartz, H.L.; Perez-Castillo, A.; Oppenheimer, J.H. Relationship of c-erbA mRNA content to tissue triiodothyronine nuclear binding capacity and function in developing and adult rats. J. Biol. Chem. 1990, 265, 10514-10521.

(C) 2019 by the authors. Licensee MDPI, Basel, Switzerland. This article is an open access article distributed under the terms and conditions of the Creative Commons Attribution (CC BY) license (http://creativecommons.org/licenses/by/4.0/). 